Heidbach, O., Rajabi, M., Cui, X., Fuchs, K., Müller, B., Reinecker, J., Reiter, K., Tingay, M., Wenzel, F., Xie, F., Ziegler, M., Zoback, M.-L., Zoback, M. (2018): The World Stress Map database release 2016: Crustal stress pattern across scales. - Tectonophysics, 744, 484-498.

https://doi.org/10.1016/j.tecto.2018.07.007 


\title{
The World Stress Map database release 2016: Crustal stress pattern across scales
}

\author{
Oliver Heidbacha,*, Mojtaba Rajabib, Xiaofeng Cuic, Karl Fuchs ${ }^{\mathrm{d}}$, Birgit Müllere, John Reineckerf, \\ Karsten Reiterg, Mark Tingayb, Friedemann Wenzeld, Furen Xiec, Moritz O. Zieglera,h, \\ Mary-Lou Zobacki, Mark Zoback ${ }^{\mathrm{i}}$ \\ a Helmholtz Centre Potsdam, GFZ German Research Centre for Geosciences, Telegrafenberg, 14473 Potsdam, Germany \\ b Australian School of Petroleum, The University of Adelaide, SA 5005, Australia \\ c Institute of Crustal Dynamics, China Earthquake Administration, 100085 Beijing, China \\ d Geophysical Institute, Karlsruhe Institute of Technology KIT, Hertzstr. 16, 76187 Karlsruhe, Germany \\ e Landesforschungszentrum Geothermie, Karlsruhe Institute of Technology KIT, Adenauerring 20b, 76131 Karlsruhe, Germany \\ f Geothermal Engineering GmbH, Baischstr. 8, 76133 Karlsruhe, Germany \\ ${ }^{g}$ Institute of Applied Geosciences, Technical University Darmstadt, Schnittspahnstr. 9, 64287 Darmstadt, Germany \\ h Institute of Earth and Environmental Science, Potsdam University, Karl-Liebknecht-Str. 24-25, 14476 Potsdam, Germany \\ i Department of Geophysics, Stanford University, 397 Panama Mall, Stanford, CA 94305, USA
}

\section{ARTICLEINFO}

Keywords:

Tectonic stress

Database

Stress tensor

Geomechanical modelling

\section{ABSTRACT}

Knowledge of the present-day crustal in-situ stress field is a key for the understanding of geodynamic processes such as global plate tectonics and earthquakes. It is also essential for the management of geo-reservoirs and underground storage sites for energy and waste. Since 1986, the World Stress Map (WSM) project has systematically compiled the orientation of maximum horizontal stress $\left(S_{H \max }\right)$. For the 30th anniversary of the project, the WSM database has been updated significantly with 42,870 data records, which is double the amount of data in comparison to the database release in 2008. The update focuses on areas with previously sparse data coverage to resolve the stress pattern on different spatial scales. In this paper, we present details of the new WSM database release 2016 and an analysis of global and regional stress pattern. With the higher data density, we can now resolve stress pattern heterogeneities from plate-wide to local scales. In particular, we show two examples of $40^{\circ}-60^{\circ} S_{\text {Hmax }}$ rotations within $70 \mathrm{~km}$. These rotations can be used as proxies to better understand the relative importance of plate boundary forces that control the long wave-length pattern in comparison to regional and local controls of the crustal stress state. In the new WSM project phase IV that started in 2017, we will continue to further refine the information on the $S_{H \max }$ orientation and the stress regime. However, we will also focus on the compilation of stress magnitude data as this information is essential for the calibration of geomechanical-numerical models. This enables us to derive a 3-D continuous description of the stress tensor from point-wise and incomplete stress tensor information provided with the WSM database. Such forward models are required for safety aspects of anthropogenic activities in the underground and for a better understanding of tectonic processes such as the earthquake cycle.

\section{Introduction}

Modern civilisation explores the Earth's crust to exploit raw materials and to withdraw or inject fluids. There is also a pressing demand to find deep geological repositories for high-level nuclear waste that are stable for one million years and to explore the possibility to sequestrate huge amounts of carbon dioxide into the underground to meet the Paris climate agreement (Kuckshinrichs and Hake, 2015; Martens et al., 2017; Pusch, 2008). These issues are major challenges for energy security and sustainability in the 21st century. In this context, the contemporary crustal in-situ stress state is a key parameter to quantify the processes that we induce into the subsurface, to mitigate e.g. induced seismicity and to provide options for an optimal usage of the underground (Hakimhashemi et al., 2014a; Henk, 2008; Müller et al., 2018; van Wees et al., 2017; Walsh

\footnotetext{
${ }^{*}$ Corresponding author.

E-mail address: heidbach@gfz-potsdam.de (O. Heidbach).

https://doi.org/10.1016/j.tecto.2018.07.007
}

and Zoback, 2016; Zoback, 2010).

Knowledge of the in-situ stress is also essential for the understanding of geodynamic processes such as global plate tectonics and earthquakes (Hardebeck, 2017; Harris, 1998; Heidbach et al., 2008; King et al., 1994; Richardson, 1992; Scholz, 1998; Steinberger et al., 2001; Zoback et al., 1989 ) as well as to mitigate induced seismicity ( $\mathrm{Ha}$ kimhashemi et al., 2014b; Gaucher et al., 2015; Segall and Fitzgerald, 1998; Zang et al., 2013). The stress evolution during the seismic cycle is one of the key processes that define the maturity of active faults and controls nucleation, rupture propagation and arrest of an earthquake (Hardebeck and Okada, 2018; Hergert and Heidbach, 2011; Oglesby and Mai, 2012; Schorlemmer and Wiemer, 2005; Stein, 1999). From the in-situ stress state the distance to a given failure criterion for any point in the subsurface can be derived. This distance is critical as it indicates the stress changes that are required for reactivation of a pre-existing fault or creation of a new fracture due to induced or natural processes (Morris etal., 1996; Schoenball et al., 2018; Walsh and Zoback, 2016). 
The World Stress Map (WSM) is the only project that compiles globally the information on the crustal stress state. It is a collaborative public-domain project between academia and industry that aims to characterize the crustal stress pattern and to understand the stress sources. The year 2016 marked the end of the third phase of the WSM project, and also the 30th anniversary of the project. In this contribution we provide details and new findings of the WSM database release 2016 with a particular emphasis on the state of crustal stress across spatial scales.

The paper opens with a short review on the basics of the stress tensor and the WSM project history followed by the presentation of the new WSM database release 2016. We then perform a global and regional analysis of the stress pattern to revisit the question whether the direction of absolute plate motion is sub-parallel to the long wavelength pattern of the orientation of maximum horizontal stress $S_{\text {Hmax }}$. Afterwards we illustrate with two examples that the increase of data records enables us to resolve stress tensor rotations of $40^{\circ}$ to $60^{\circ}$ within $<70 \mathrm{~km}$ in some regions. The contribution closes with the perspective of the WSM project and how the database will be further developed in the future. Furthermore, we demonstrate with an example that a long-term vision is to derive from the sparse and incomplete point-wise stress information a 3 -D continuous description of the stress tensor across different scales from boreholes to plate-wide regions. This is essential to quantify the criticality of the crustal stress state and to determine the distance to failure.

\section{The World Stress Map project}

\subsection{Basics of the stress tensor}

The key definitions of the stress tensor concept that are needed to set the framework used in the WSM project are summarized in Fig. 1. To describe the stress state at an arbitrary point a second rank tensor with nine components is defined, but due to its symmetry properties only six components are independent from each other. A formal derivation and further details can be found in standard text books (Engelder, 1992; Fjaer et al., 2008; Jaeger et al., 2007; Zang and Stephansson, 2010; Zoback, 2010).

With the assumption that the vertical stress $S_{V}$ is one of the three principal stresses (Fig. 1c) the $S_{H \max }$ orientation determines the orientation of the stress tensor. Given that $S_{V}$ can be calculated when rock density as a function of depth is known the remaining unknowns are the magnitudes of $S_{H \max }$ and $S_{\text {hmin }}$, the minimum horizontal stress. It is important to note that the $S_{H \max }$ orientation is the only component of the stress tensor that can be derived from all stress indicators that are used in the WSM database. Details on individual stress indicators can be found in standard text books (e.g. Amadei and Stephansson, 1997; Zang and Stephansson, 2010; Zoback, 2010) and key papers (Bell, 1996a; Célérier, 2010; Haimson and Cornet, 2003; Ljunggren et al., 2003; Maury et al., 2013; Schmitt et al.,
2012; Sperner et al., 2003).

Further information which is provided for subsets of the WSM database is the stress regime, i.e. the relative magnitudes of the three principal stresses (Fig. 1d-f). A few data records also provide information on the stress magnitudes of $S_{\text {hmin }}$ derived e.g. from hydraulic fracturing or all three principal stress magnitudes from overcoring methods, but this information is provided without a quality check for reliability or comparability of individual stress indicator.

\subsection{History of the WSM project}

The first stress data compilation of the intra-plate crustal stress state was published in the early seventies to investigate Voight's hypothesis, which stated that the contemporary compressive crustal stress pattern is controlled by the same forces that drive plate tectonics (Voight, 1966; Voight et al., 1968). Sbar and Sykes (1973) compiled 39 data records from earthquake focal mechanisms, overcoring and hydraulic fracturing measurements and could confirm this hypothesis for North America with this small data set. First global compilations were published by Hast (1973), Ranalli and Chandler (1975), Brown and Hoek (1978), and Richardson et al. (1979) using different stress indicator types and providing data sets on global crustal stress with up to 150 data records. These publications, the start of the systematic global estimation and compilation of earthquake focal mechanism (Dziewonski et al., 1981) and the finding that borehole breakouts can be used as a stress indicator (Bell and Gough, 1979; Plumb and Hickman, 1985; Zoback et al., 1985), initiated the WSM as a project of the International Lithosphere Program in 1986. Focus of the WSM in this initial phase was to compile intraplate stress data information to investigate the long wavelength of the crustal stress pattern.

In comparison to earlier compilations, the major advancement of the WSM project in its first phase is the application of a quality-ranking scheme developed by Zoback and Zoback $(1989,1991)$. This WSM quality ranking ensures the global comparability of the different stress indicators that originate from geological and geophysical data as well as from engineering methods. This collaborative attempt resulted in the first comprehensive global compilation that had 3574 data records on the $S_{H \max }$ orientation (Zoback et al., 1989). The WSM also provides a defined approach for the stress regime assignment based on the spatial orientation in terms of trend and plunge of the P-, Tand $\mathrm{B}$-axes derived from earthquake focal mechanisms (Müller et al., 1992; Zoback, 1992). The analysis of this comprehensive global compilation of crustal stress information showed that most intraplate regions are characterized by compressional or strike slip stress regime except for areas with high elevation where normal stress regime is prevailing. They also found that the wave-lengths of the $S_{H \max }$ stress pattern can be several thousand kilometres 


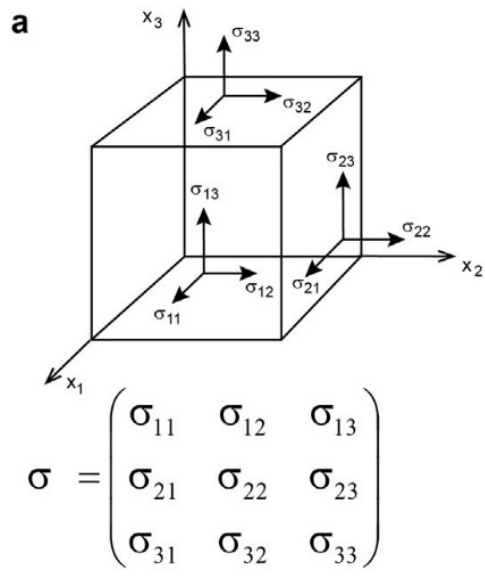

d

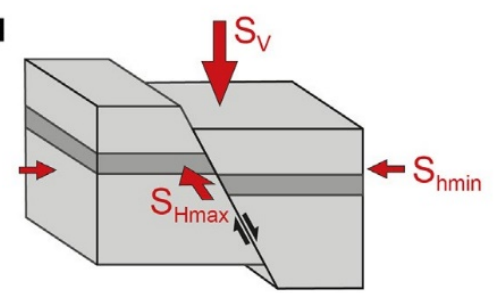

Normal Faulting (NF)

$\mathrm{S}_{\mathrm{V}}>\mathrm{S}_{\mathrm{H} \max }>\mathrm{S}_{\mathrm{hmin}}$ b

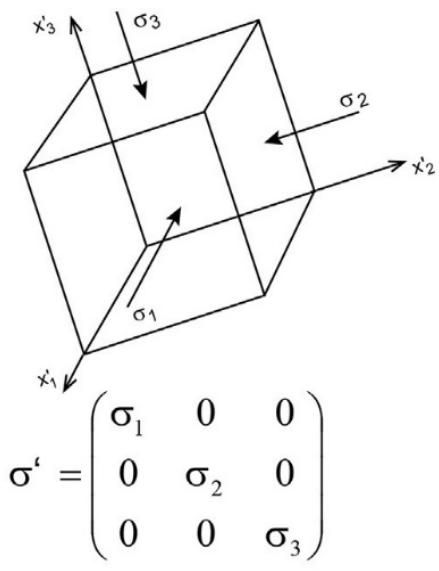

e

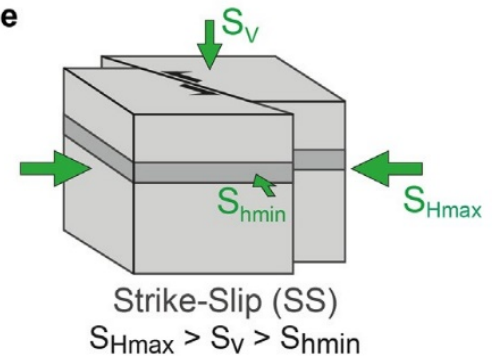

c

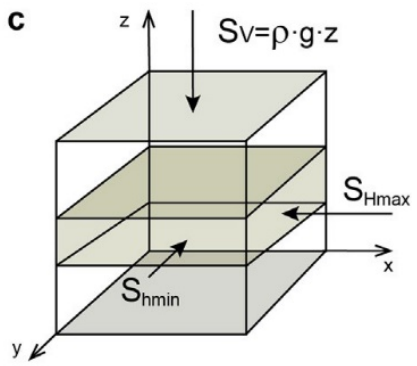

$S=\left(\begin{array}{ccc}S_{V} & 0 & 0 \\ 0 & S_{H_{\max }} & 0 \\ 0 & 0 & S_{h_{\min }}\end{array}\right)$

f

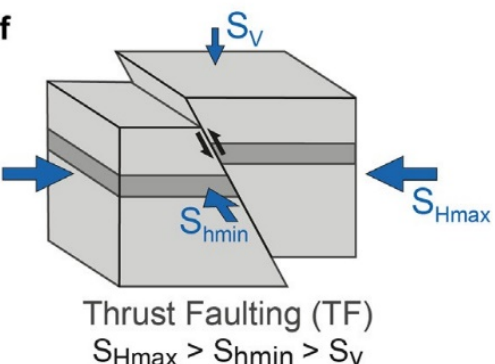

Figure 1. a) The components of the stress tensor define the stress state at a point and enable to compute the stress vector on any surface within a body. To describe the stress tensor components an infinitely small cube with unit surfaces is used. The forces acting on the cube faces can be decomposed in forces acting parallel and those acting normal to the surface. The first create the normal stress components, the second create the shear stress components of the stress tensor. b) Due to the conservation of momentum the stress tensor has to be symmetric. This implies that a coordinate system exists where shear stresses vanish along the faces of the cube. In this principal axis system, the remaining three stresses are the principal stresses. c) Assuming that the vertical stress in the Earth crust $S_{V}=g \cdot \rho \cdot z$ is a principal stress ( $g$ is gravitational acceleration, $\rho$ is the rock density, $z$ the depth), the two horizontal stresses $S_{\text {hmin }}$ and $S_{H \max }$, the minimum and maximum horizontal stress, respectively, are principal stresses as well. This so-called reduced stress tensor is fully determined with four components: the $S_{H \max }$ orientation and the magnitudes of $S_{V}, S_{H \max }$ and $S_{\text {hmin }}$. The stress information provided in the WSM database is for all data records the $S_{H \max }$ orientation and for most data records the stress regime which indicates the relative stress magnitudes. d) Normal faulting stress regime where $S_{V}$ is larger than the horizontal stresses $\left(S_{V}=\sigma_{1}\right)$. e) Strike-slip faulting stress regime where $S_{V}$ is the intermediate principal stress $\left(S_{V}=\sigma_{2}\right)$. f) Thrust faulting stress regime where $S_{V}$ is smaller than the horizontal stresses $\left(S_{V}=\sigma_{3}\right)$.

and that the trend of the $S_{H \max }$ orientation in some tectonic plates is sub-parallel with the direction of absolute plate motion (Richardson, 1992; Richardson et al., 1979; Zoback, 1992; Zoback et al., 1989).

The second phase of the WSM project took place from 1996 to 2008 at the Heidelberg Academy of Sciences and Humanities. During this period, the project intensified the compilation from borehole data and started to include stress information from plate boundary zones as well (Heidbach et al., 2010; Sperner et al., 2003). In 1998, the WSM project went online to make the data publically available and to provide the fully automatic online service CASMO (Create A Stress Map Online) for user-specific stress map production (Heidbach et al., 2004). The complementary stand-alone tool CASMI (Create A Stress Map Interactively) for user-specific stress map generation with an extended functionality was released at the end of the second WSM project phase (Heidbach and Höhne, 2008). The significant increase to 21,750 data records in the WSM database release 2008 revealed that plate boundary forces are not enough to fully explain the crustal stress pattern of the $S_{\text {Hmax }}$ orientation (Heidbach et al., 2007; Heidbach et al., 2010; Tingay et al., 2005). Density and rock strength contrasts, detachment horizons due to low shear strength lithologies (e.g. salt layer), faults, flexural stresses and basin geometry can have a major impact on the regional and local stress pattern (Assumpcao and Sacek, 2013; Bell, 1996b; Heidbach et al., 2007; Sonder, 1990; Tingay et al., 2005; Tingay et al., 2006; Zoback and Richardson, 1996; Zoback, 1992).

The third phase of the WSM project commenced in 2009 with the transfer to the Helmholtz Centre Potsdam, GFZ German Research Centre for Geosciences where the WSM is still maintained. During this phase, the project became a member of the World Data System of the International Council for Science (ICSU). This phase of the WSM project involved intensified international collaboration and fully integrated new or updated national stress compilations from e.g. Australia, Canada, China, Germany, Iceland, Italy, New Zealand and Switzerland. The resulting current WSM database release 2016 has 42,870 data records, with $>22,000$ new ones and the revision of $>2000$ data records. The end of the third phase in 2016 marked the 30th anniversary of the project for which we released the new World Stress Map (Fig. 2). Details of this new global stress map and the new WSM database compilation 


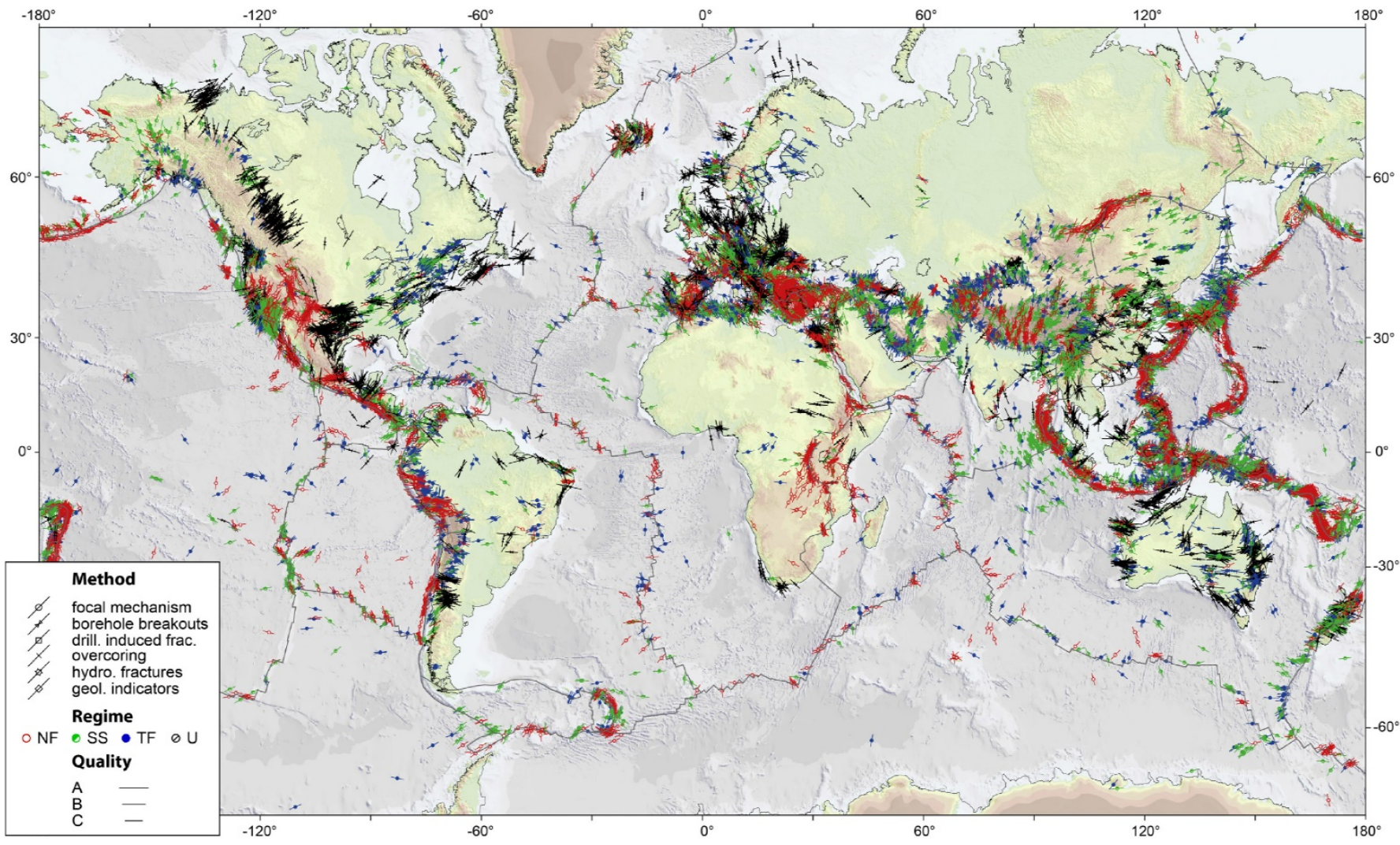

Figure 2. The World Stress Map (WSM) 2016 displays the contemporary crustal stress orientation in the upper 40 km based on the WSM database release 2016 . Lines show the orientation of maximum horizontal stress $\left(S_{H \max }\right)$ from different stress indicators displayed by different symbols; line length is proportional to data quality. Displayed are the 20,757 data records with A-C quality according to the WSM quality ranking scheme except those that are labelled as possible plate boundary events (Heidbach et al., 2010). Colours of the symbols and lines indicate the stress regime with red for normal faulting (NF), green for strike-slip (SS), blue for thrust faulting (TF) and black for unknown (U) stress regime (see Fig. 1d-f). Plate boundaries are taken from PB2002 (Bird, 2003), topography is based on the ETOP01 data from the National Geophysical Data Centre (NGDC) including bathymetry data from Amante and Eakins (2009). This map can be accessed and downloaded in high resolution at https://doi.org/10.5880/WSM.2016.002.

are presented in the next section.

\subsection{The WSM database release 2016}

Table 1 presents the number of data records according to the stress indicator type and data quality for the WSM database release 2008, the new data records and the WSM database release 2016. The WSM database uses stress indicators from earthquake focal mechanisms (e.g. individual earthquake focal mechanism FMS and stress inversion of focal mechanisms FMF), interpretation of geophysical logs (borehole breakouts BO and drilling induced tensile fractures DIF), engineering methods (hydraulic fracturing methods HF and overcoring OC), and geological data (fault slip analysis GFI, volcanic alignments GVA). The database also contains data from several other methods that are either rarely used nowadays (composites of focal mechanisms FMA, borehole slotter BS, petal centreline fractures PS) or are relatively new (shear wave splitting in boreholes SWB). Details on individual stress indicators are presented in a number of textbooks and review papers (e.g. Alt II and Zoback, 2017; Amadei and Stephansson, 1997; Bell, 1996a; Célérier, 2010; Fjeldskar, 1995; Haimson and Cornet, 2003; Ljunggren et al., 2003; Maury et al., 2013; Schmitt et al.,
2012; Sperner et al., 2003; Zang and Stephansson, 2010; Zoback, 2010). Specific technical details such as abbreviations used in the WSM database, analysis guidelines, the stress regime assignment, the WSM quality ranking scheme and the explanation of the individual fields of each data record is given in the WSM Scientific Technical Reports which is provided for download on the project website at www.world-stress-map.org.

Each data record has been quality-ranked based on the WSM quality ranking system from A to E quality. A-quality data indicate that the $S_{H \max }$ orientation is accurate to within $\pm 15^{\circ}$, B-quality to within $\pm 20^{\circ}$, C-quality to within $\pm 25^{\circ}$, D-quality to within $\pm 40^{\circ}$. E-quality is assigned to data records with incomplete, non-reliable information or when the standard deviation is $> \pm 40^{\circ}$. For the new WSM database release 2016 we applied the most recent version of the WSM quality ranking scheme published in Heidbach et al. (2010).

The majority of data records in the WSM database are from earthquake focal mechanism (single events FMS and formal stress inversion of several events FMF) and borehole data (Table 1 ). In the new release of the WSM, we compiled $\sim 16,500$ data records based on earthquake data 
Table 1

Number of data records in the WSM database according to stress indicator and data quality.

\begin{tabular}{|c|c|c|c|c|c|c|}
\hline Stress indicator type & \multicolumn{2}{|c|}{ WSM 208} & \multicolumn{2}{|c|}{ New data records } & \multicolumn{2}{|c|}{ WSM $2016^{a}$} \\
\hline Focal Mechanisms Single (FMS) & 14,447 & 13,081 & $16,519^{b}$ & $14,274^{b}$ & $30,341^{\mathrm{c}}$ & $26,730^{c}$ \\
\hline Borehole Breakouts (BO, BOC, BOT) & 4125 & 2168 & 2640 & 1204 & 6301 & 2962 \\
\hline Drilling Induced Tensile Fracture (DIF) & 278 & 82 & 663 & 352 & 941 & 430 \\
\hline Hydraulic Fracturing (HF, HFG, HFM, HFP) & 349 & 228 & 566 & 129 & 907 & 341 \\
\hline Other (BS, FMA, PC, SWB, SWL, SWS) & 357 & 9 & 208 & 69 & 565 & 78 \\
\hline Sum & 21,750 & 16,969 & 22,269 & 16,587 & 42,870 & 32,465 \\
\hline
\end{tabular}

a Sum of data records from the WSM database release 2008 and new data does not equal the total number since double entries of focal mechanisms and erroneous data entries were deleted from the WSM database release 2008. Furthermore, completely revised data records in particular for borehole data from China and Switzerland were also marked as new data entries since they were partly completely re-analysed from raw log data.

b 6144 of the new FMS data records are flagged as Possible Plate Boundary Events (PBE) which indicates that they have a higher possibility not to show within the given C-quality $\left( \pm 25^{\circ}\right.$ ) assignment the $S_{H \max }$ orientation (details on the procedure are given in Heidbach et al., 2010).

c 11,708 of the FMS data records are flagged as Possible Plate Boundary Events (PBE).

and $\sim 4000$ new data records from borehole data through interpretation of borehole breakouts (BO), drilling induced tensile fractures (DIF), hydraulic fracturing methods (HF), and shear wave splitting in boreholes (SWB).

This significant increase of data records in the WSM database release 2016 could be achieved due to the integration of the Chinese Crustal Stress Database (Hu et al., 2017; Xie et al., 2007), the new Australian stress map database (Rajabi et al., 2017b) and comprehensive individual regional and national studies on the crustal stress field in $\mathrm{Ar}$ gentina (Guzmán and Cristallini, 2009; Guzmán et al., 2007), Canada (Konstantinovskaya et al., 2012; Reiter et al., 2014), Great Britain (Kingdon et al., 2016; Williams et al., 2015), Germany (Reiter et al., 2016), Iceland (Ziegler et al., 2016b), Italy (Montone and Mariucci, 2016; Pierdominici and Heidbach, 2012), New Zealand (Rajabi et al., 2016b; Townend et al., 2012), USA (Alt II and Zoback, 2017; Hurd and Zoback, 2012; Lund Snee and Zoback, 2016), South Africa (Marco Andreoli and Andrew Logue pers. comm.), South America, (Assumpcao et al., 2016), and Switzerland (Heidbach and Reinecker, 2013).

\section{4. $S_{H \max }$ rotation with depth}

The depth distribution of A-C quality data records presented in Fig. 3a, b shows that the number of stress data records is decreasing with depth and that all types of stress indicator are available in the upper five kilometres. Below that depth, earthquake focal mechanisms and stress inversions of focal mechanisms are the only available stress indicators, except for a few deep scientific boreholes (e.g. Brudy et al., 1997; Lund and Zoback, 1999). The majority of data records with A-C quality are earthquake focal mechanisms, which receive at best a $\mathrm{C}$-quality due to intrinsic uncertainties when the P-, B- and T-axis of the focal mechanism are taken as proxies for the principal stress orientations (Célérier, 2010; Heidbach et al., 2010; McKenzie, 1969; Wallace, 1951). This explains why $68 \%$ of the data records received a C-quality.
Plotting the data in stress maps assumes that there is, in average, no significant rotation with depth. Pierdominici and Heidbach (2012) tested this in detail for Italy and concluded that the deviation between the $S_{H \max }$ orientation at depth $>5 \mathrm{~km}$ from earthquake focal mechanisms and from data records in the upper $5 \mathrm{~km}$ is within the uncertainty of the data records. This finding is confirmed to first order with the global data set from the WSM database release 2016. Fig. 3c shows the distribution of the deviation between a $S_{H \max }$ orientation from a shallow data record ( $\leq 5$ $\mathrm{km})$ and a $S_{\text {Hmax }}$ orientation derived from a focal mechanism from depth $>5 \mathrm{~km}$ within a lateral search radius of 25 and $100 \mathrm{~km}$, respectively. 82 and $74 \%$, respectively, of the deviations are within $\pm 25^{\circ}$. Given that the majority of the data records from greater depth are assigned to C-quality (i.e. $S_{\text {Hmax }}$ is reliable within $\pm 25^{\circ}$ ) this results indicates that, on a global scale, the variability of the $S_{H \max }$ orientation with depth is usually small and justifies the presentation of the depth-stacked $S_{\text {Hmax }}$ orientation data in map view. However, it should be noted that the relatively constant $S_{\text {Hmax }}$ orientation with depth does not imply that the stress tensor is constant with depth, because stress magnitudes obviously increase with increasing overburden. Furthermore, changes of the stress regime can occur as the increase of $S_{v}$ with depth which is generally larger than the increase of horizontal stress magnitudes with depth. This is expressed in a decreasing ratio between the magnitude of the mean horizontal stress and the vertical stress (Brown and Hoek, 1978; Sheorey, 1994; Zang et al., 2012). It means the changes of stress magnitudes and stress regime with depth do not necessarily leave a signal in the $S_{\text {Hmax }}$ orientation. The same arguments can be discussed for areas where there are lateral variations of the $S_{H \max }$ orientation. Our new compilation indicates that the $S_{H \max }$ orientation is laterally more sensitive to the stress tensor variability than in the vertical direction (see Section 4). However, the scales are different as with depth we only have a good resolution in the upper $15 \mathrm{~km}$ (Fig. 3) and lateral stress rotations are in general not resolved at $10 \mathrm{~km}$ 


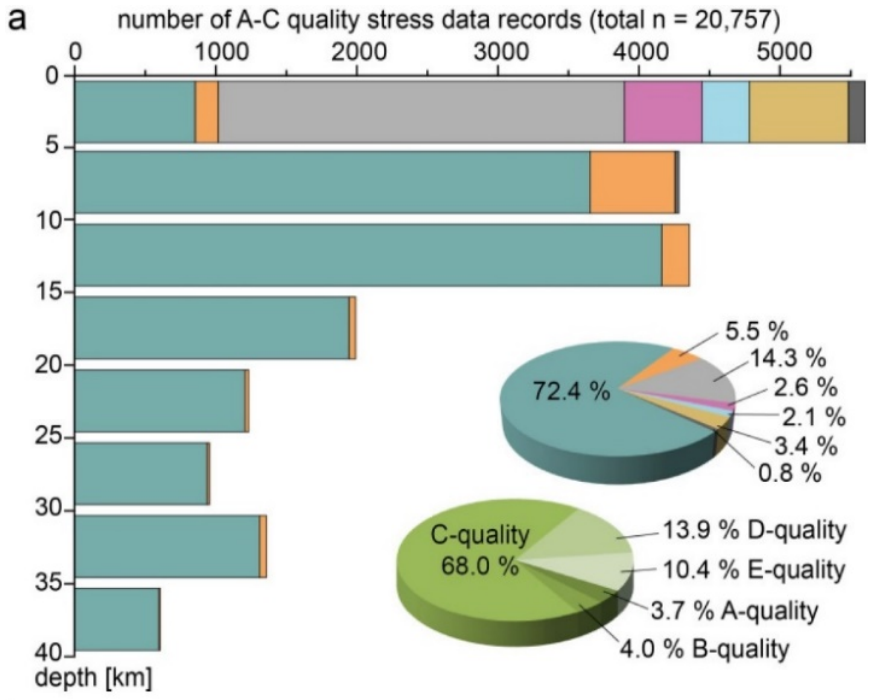

b

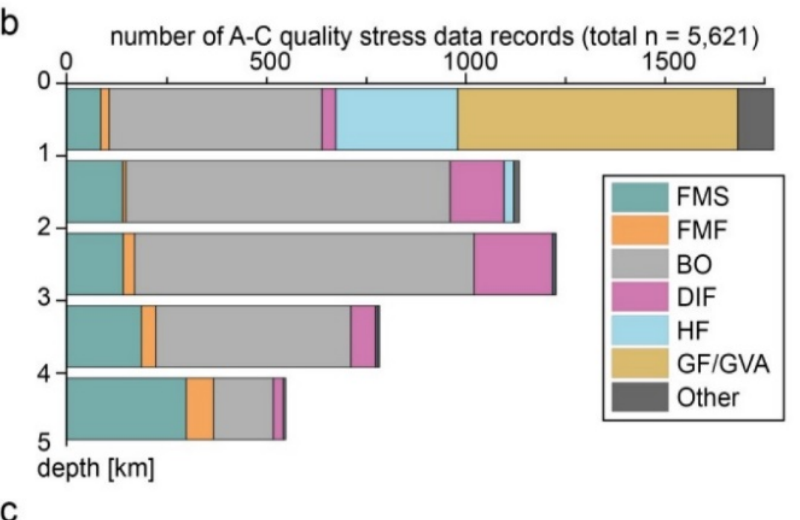

number of data pairs

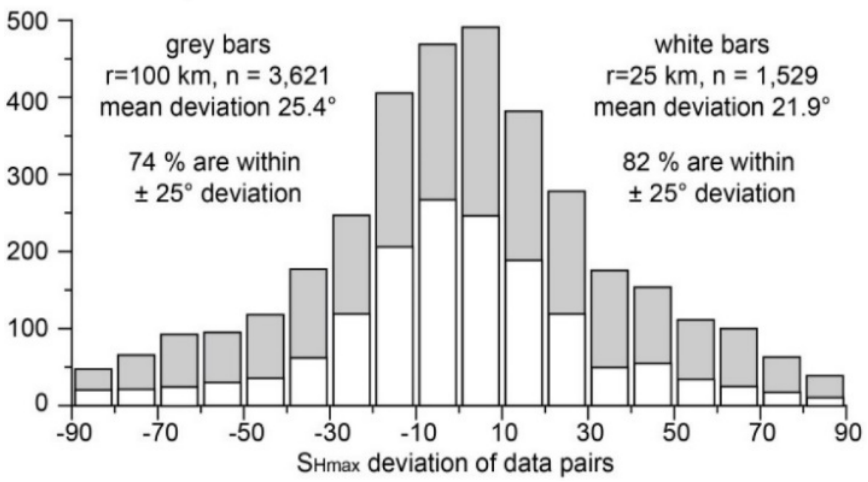

Figure 3. a) Depth and data type distribution of A-C quality data records and quality distribution of all data records in the WSM database release 2016. FMS: single earthquake focal mechanism, FMF: stress inversion using focal mechanisms; BO borehole breakouts; DIF: drilling induced tensile fractures; HF: hydraulic fracturing; GF: inversion of fault slip data; GVA: geological volcanic alignments. Note that data from FMS and FMF are almost the only stress indicator at depth $>5 \mathrm{~km}$. b) Distribution of data records with A-C quality within the upper $5 \mathrm{~km}$ of the Earth's crust. c) Distribution of the deviation of $S_{\text {Hmax }}$ orientation from a data record from $\leq 5 \mathrm{~km}$ depth and the nearest FMS/ FMF data record from depth $>5$ $\mathrm{km}$ within a $100 \mathrm{~km}$ (grey and white bars) and $25 \mathrm{~km}$ (white bars only) search radius, respectively. The mean deviation is similar to or smaller than the reliability of the C-quality data (i.e. the $S_{H \max }$ orientation is reliable within $\pm 25^{\circ}$ ) indicating that the $S_{H \max }$ orientation is not varying significantly with depth. scale.

At specific geological settings, however, e.g. when horizons with very low shear strength mechanically decouple layers, large $S_{\text {Hmax }}$ rotations of $>45^{\circ}$ within a few hundred meters depth are reported as well (Cornet and Röckel, 2012; Heidbach et al., 2007; Roth and Fleckenstein, 2001; Tingay et al., 2011; Zakharova and Goldberg, 2014). Furthermore, Schoenball and Davatzes (2017) speculate that potential rotations of the $S_{\text {Hax }}$ orientation in the upper few kilometres are hidden by the procedure of WSM quality assignment for borehole data. Unless a significant and instant change of the derived $S_{H \max }$ orientation is detected within a borehole log, each data record contains only a mean $S_{H \max }$ value for the whole length of the borehole. This value is derived from the mean orientation of the picked borehole breakouts and drilling induced tensile fractures weighted by their individual length. Schoenball and Davatzes (2017) found that the longer the total length of breakout zones or drilling induced fractures is, the larger is in a global average the standard deviation of the derived $S_{H \max }$ orientation. However, the increase of the standard deviation is smaller than our comparison of the deviation within the $\pm 25^{\circ}$ corridor.

\section{Global crustal stress pattern}

During the initial phase of the WSM project the global stress pattern has been investigated by Zoback et al. (1989) and Zoback (1992). Amongst other findings they showed that the $S_{\text {Hmax }}$ orientation from individual data records is often sub-parallel to the direction of absolute plate motion indicating that the forces that drive plate motion also control the first-order intra-plate crustal stress pattern. In the following, we revisit this hypothesis as the number of data records has increased significantly in comparison to the first release of the WSM project. However, instead of using the $S_{H \max }$ orientation from individual data records, we use mean $S_{H \max }$ orientations on a regular grid from a smoothed stress field. Smoothing means that we filter the long wavelength signal of the stress pattern. This suppresses the impact of local variability in the data and avoids that spatial cluster of data records are over-represented in the analysis. We first present in Section 3.1 our new smoothing tool stress2grid and present in the subsequent sections two differently smoothed stress maps and the comparison of these with absolute plate motion direction.

\subsection{New smoothing tool stress2grid}

To analyse the wave-length of the crustal stress pattern we use so-called smoothed stress maps that show the mean $S_{\text {Hmax }}$ orientation on regular grids. Based on the work of $\mathrm{Co}$ blentz and Richardson (1995), Müller et al. (2003), and Heidbach etal. (2010) we wrote the Matlab ${ }^{\circledR}$ script stress2grid (Ziegler and Heidbach, 2017a) which extends and speeds up the analysis possibilities. Furthermore, the 


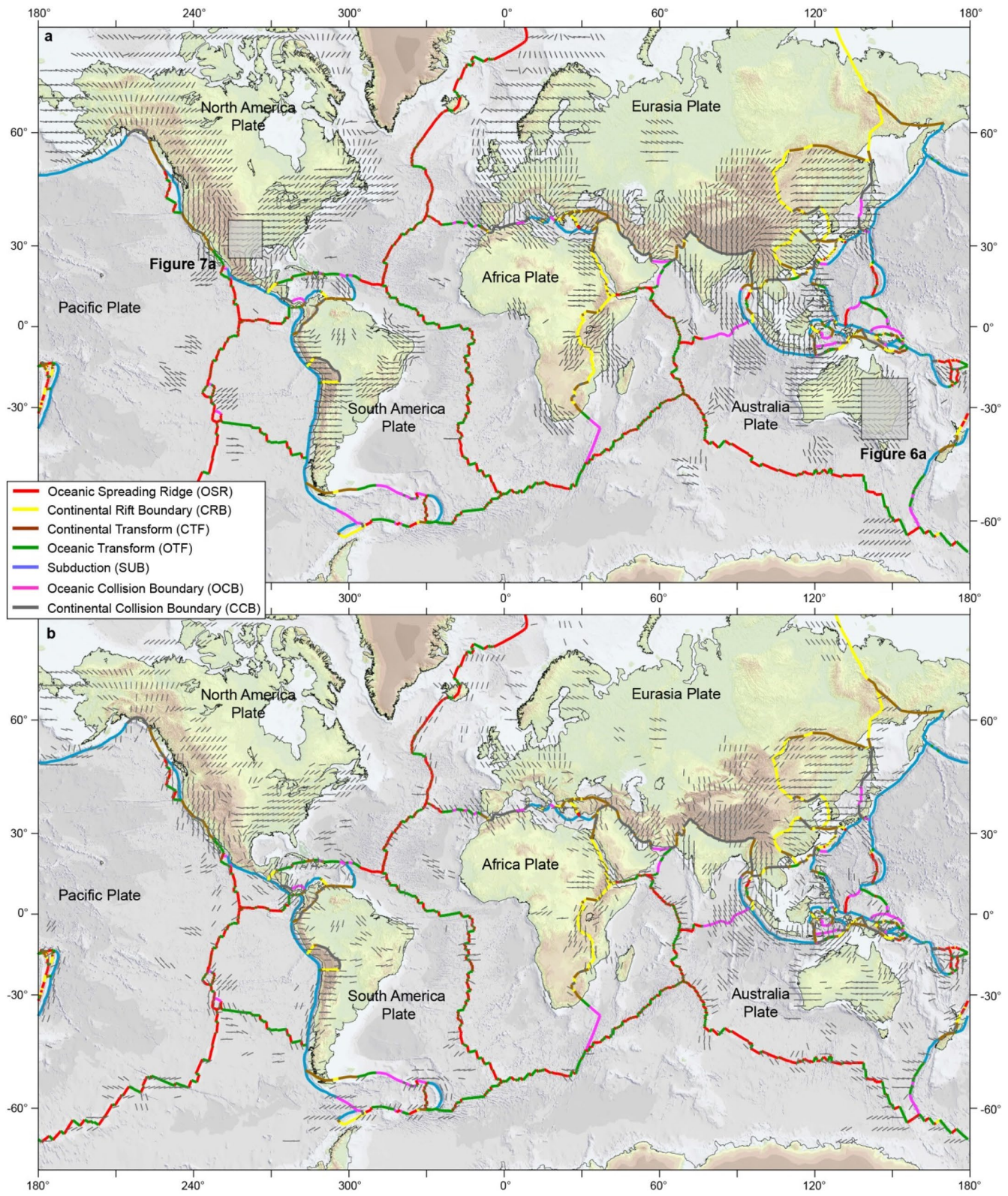

Figure 4. a) Smoothed global intra-plate stress maps with a fixed search radius of $500 \mathrm{~km}$. Mean $S_{H \max }$ orientation is calculated on a $2^{\circ}$ global grid using A-C quality data without PBE flag. Furthermore, only data records located on the same tectonic plate as the grid point is used to calculate the mean $S_{H \max }$ orientation. Minimum number of data records within the search radius is $\mathrm{n}=5$ and data records within a distance of $d \leq 200 \mathrm{~km}$ to the nearest plate boundary are not used. Plate boundaries are taken from the global model PB2002 from Bird (2003). Furthermore, a distance and data quality weight are applied; the distance threshold is set to $10 \%$ of the search radius. b) Same settings as above, but now variable search radii are used. Search radius starts with $1000 \mathrm{~km}$ and is decreased in $100 \mathrm{~km}$ steps down to $100 \mathrm{~km}$. Mean $S_{\text {Hmax }}$ orientation is taken and plotted here for the largest search radius when the standard deviation of the mean $S_{H \max }$ orientation at the individual grid points is $\leq 25^{\circ}$.

script can compute the plate motion from Euler vectors and estimates the deviation of the mean $S_{H \max }$ orientation to the plate motion direction.

The script provides two different approaches to calculate the mean $S_{H \max }$ orientation on regular grids both based on the directional statistics of circular and axial data (Mardia, 1972; Davis, 1986). The first is using a constant search radius around the grid point and computes the mean $S_{H \text { max }}$ orientation if sufficient data records are within the user-defined fixed search radius (Fig. 4a). This can result in mean $S_{\text {Hmax }}$ orientations with a high standard deviation of the individual mean $S_{H \max }$ orientation and it may hide local perturbations. Thus, the mean $S_{H \max }$ orientation is not necessarily reliable for a local stress field analysis. The second approach is using variable search radii and determines the search radius for which the standard deviation of the mean $S_{\text {Hmax }}$ orientation is below a userdefined threshold. This approach delivers the mean $S_{H \max }$ orientations with a user-defined degree of reliability. It resolves local stress perturbations and is not available in areas with no data or conflicting information that result in a large standard deviation of the mean $S_{H \max }$ orientation. 

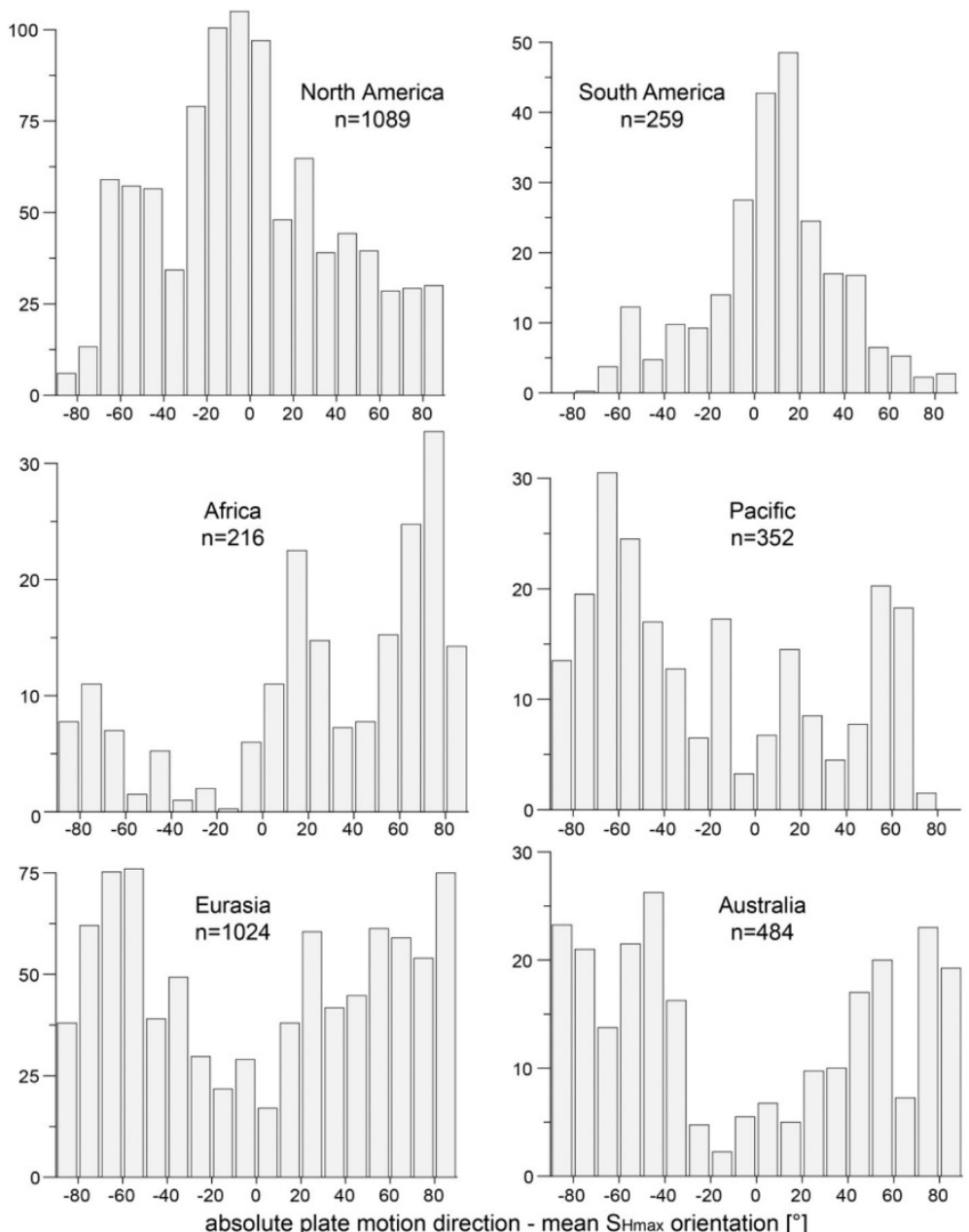

Figure 5. Deviation between absolute plate motion direction and mean $S_{H \max }$ orientation. The absolute plate motion direction is estimated from the model HS3 NUVEL1A (Gripp and Gordon, 2002). For the mean $S_{H \max }$ orientations the results from a global $1^{\circ}$ grid are taken with the same search parameter as stated in Section 3.2. The number $n$ indicates the total number of grid points that returned a mean $S_{H \max }$ orientation value.

\subsection{Mean $S_{\text {Hmax }}$ orientation on regular grids}

Fig. 4a shows the pattern of the mean $S_{H \max }$ orientation calculated with a fixed search radius of $r=500 \mathrm{~km}$ on a global $2^{\circ}$ grid. Within this search radius, only data records are used that are a) not flagged as PBE (see Heidbach et al. (2010) for details on the flagging procedure), b) that are located on the same tectonic plate as the grid point using the plate boundary definitions of the global tectonic model PB 2002 of Bird (2003) and c) are not within a distance of $200 \mathrm{~km}$ of the nearest plate boundary. The minimum number of data records that are requested to calculate the mean $S_{H \max }$ orientation is set to $n=5$. Each data record is weighted according to data quality and distance to the grid point, but data records within $10 \%$ of the search radius (here $50 \mathrm{~km}$ ) around the grid point receive the same distance weight to avoid that data close to the grid point are over-represented in the calculation of the mean $S_{H \max }$ orientation. Avoiding data records that are close to plate boundaries put the emphasis of the smoothing to the long wave-length intra-plate stress pattern. Note that the mean $S_{\text {Hmax }}$ orientation displayed in Fig. 4 a is not necessarily a reliable $S_{H \max }$ orientation at the grid points. It is rather a filtered long wave-length mean $S_{H \max }$ orientation. Local deviations which can be significant in areas with e.g. active tectonics, local topography or other sources that alter the local stress field are not necessarily resolved with the chosen search radius of $500 \mathrm{~km}$.

Fig. 4 b presents the mean $S_{\text {Hax }}$ orientation on a global $2^{\circ}$ grid using variable search radii. The calculation starts with a search radius of $r=1000 \mathrm{~km}$ and is decreased in $100 \mathrm{~km}$ steps down to $100 \mathrm{~km}$. On the stress map, the mean $S_{\text {Hmax }}$ orientation value is plotted for the largest search radius where the standard deviation is $\leq 25^{\circ}$. Further details on the procedure are described in Heidbach et al. (2010) and Ziegler and Heidbach (2017b). Within the search radii, we used the same criteria of data selection similar to Fig. 4a. Each data record is weighted according to its assigned quality and the distance to the grid point. Data records within $10 \%$ of the respective search radius receive the same distance weight to avoid an over-representation of data records close to the grid point. The resulting smoothed stress map (Fig. 4b) shows reliable mean $S_{\text {Hmax }}$ orientation within $\pm 25^{\circ}$ on a regular grid. These values can 


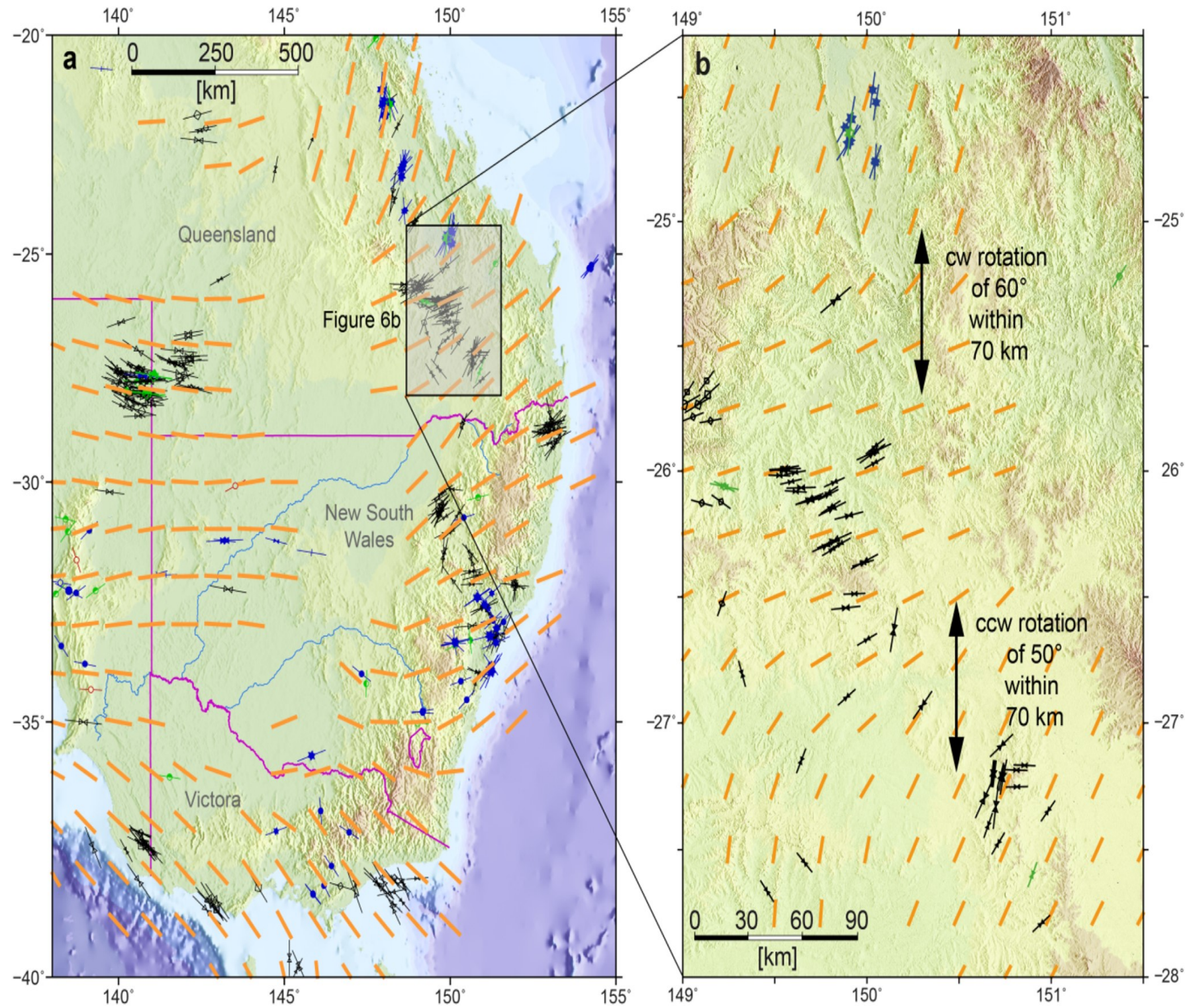

Figure 6. a) Stress map of Eastern Australia. Orange bars display the mean $S_{\text {Hmax }}$ orientation calculated on a $1^{\circ}$ grid with a search radius of $250 \mathrm{~km}$ using data quality and distance weights. Minimum number of data records required for the estimation of a mean $S_{H \max }$ estimation is $n=5$. Thin purple lines are state borders. b) Local stress pattern in the Surat and Bowen basins in south-eastern Queensland on a $0.25^{\circ}$ grid estimated with a fixed search radius $r=75 \mathrm{~km}$ and a data quality and distance weight. Minimum number of data records required for the estimation of the mean $S_{H \max }$ is $n=5$.

be used as a first-order prediction for applied purposes on local to regional scales.

For both approaches presented in Section 3.1 and this section various global smoothed stress data sets are available (Heidbach and Ziegler, 2018). Herein, the smoothed stress data for four global grids $\left(0.2^{\circ}, 0.5^{\circ}, 1^{\circ}\right.$, and $2^{\circ}$ grid spacing) using two fixed search radii (250 and $500 \mathrm{~km})$ and the approach with variable search radii as explained above are provided.

\subsection{Mean $S_{H \max }$ orientation versus absolute plate motion direction}

To re-examine the hypothesis whether absolute plate motion direction is sub-parallel to the $S_{H \max }$ orientation, we use the smoothed mean $S_{H \max }$ orientation on a global $1^{\circ}$ grid. We use a fixed search radius of $500 \mathrm{~km}$ with the same data selection criteria as for the smoothed stress map displayed in Fig. 4a. At each grid point we estimate the deviation between the mean $S_{H \max }$ orientation and the absolute plate motion direction using the global hot spot referenced tectonic plate model HS3 NUVEL-1A (Gripp and Gordon, 2002). Even though the number of data records has increased significantly (and thus the number of grid points where a mean $S_{H \max }$ orientation can be estimated) in comparison to the first analysis in Zoback et al. (1989), the histogram shows similar deviation distributions for most of the chosen plates (Fig. 5). This finding is in-sensitive to the incorporated smoothing approach, the smoothing parameter setting, or if we would use the $S_{H \max }$ orientations 


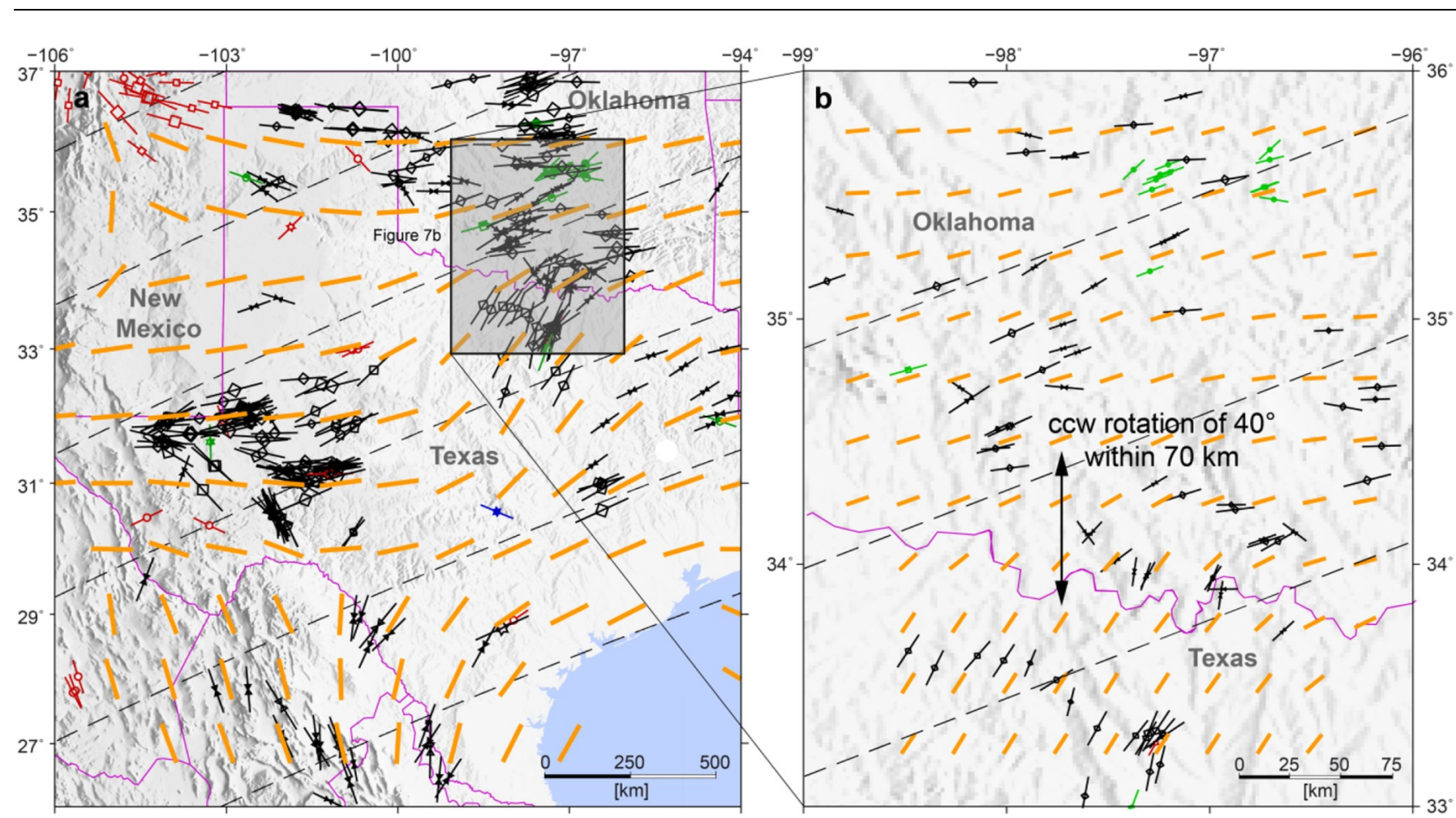

Figure 7. a) Crustal stress pattern of south-central U.S. Orange bars display the mean $S_{H \max }$ orientation calculated on a $1^{\circ}$ grid with a fixed search radius of $250 \mathrm{~km}$ using data quality and distance weights. Minimum number of data records required for the estimation of a mean $S_{H \max }$ estimation is $n=5$. Thin purple lines are state borders. b) Local stress pattern on a $0.25^{\circ}$ grid estimated with a fixed search radius $r=75 \mathrm{~km}$ and a data quality and distance weight. Minimum number of data records required for the estimation of a mean $S_{\text {Hmax }}$ estimation is $n=5$.

from individual stress data records rather than mean $S_{\text {Hmax }}$ orientations on global grids.

A large difference, however, in contrast to the findings of Zoback et al. (1989), is revealed for the Eurasian plate. Here, the Euler pole has changed significantly in comparison to the hotspot reference model from Minster and Jordan (1978) that was applied in 1989. Furthermore, we do not distinguish between sub-regions of the Eurasian plate. For Western Europe, north of the Alps, the mean $S_{H \max }$ orientation is still approximately $140^{\circ} \mathrm{N}$. This orientation is in line with the relative plate motion direction between the Africa plate and the Eurasia plate as revealed by Müller et al. (1992) using the first WSM database release. In addition, several authors using geomechanical-numerical 2D models have shown that the push from the North Atlantic ridge and the continental collision of the Africa, along the Alpine chain, are the key control of the general $S_{H \max }$ trend in Central Western Europe (Gölke and Coblentz, 1996; Grünthal and Stromeyer, 1986, 1992).

The most significant increase of data records is seen in Australia where $<100$ reliable data records were available in 1992 (Zoback, 1992) and 319 data records in 2000 (Hillis and Reynolds, 2000, 2002). The new Australian stress map with > 2000 data records (Rajabi et al., 2017b) confirms earlier speculations that the Australian plate has a very complex stress pattern. This is most likely due to various plate boundary forces that are acting in different directions and with different magnitudes leading to a super- position and regional changes of the mean $S_{H \max }$ orientation. The first attempts to explain the variability of the crustal stress field in Australia was made by Cloetingh and Wortel $(1985,1986)$ followed by studies e.g. from Coblentz et al. (1995), Reynolds et al. (2002), and Dyksterhuis et al. (2005). These studies have in common that they use 2-D geomechanical-numerical models to estimate an optimal set of plate boundary forces to fit the observed stress pattern variability in Australia. However, the substantial update of the Australian stress map database revealed that deviations from these models occur in the new and better resolved stress provinces (Rajabi et al., 2017b). A new 3-D geomechanical-numerical model presented by Rajabi et al. (2017a) provides a good fit to the updated database and reviews in detail all earlier model approaches.

2-D geomechanical-numerical models were also presented for the Africa and South America plate showing that the plate boundary forces are a key contributor to the observed stress pattern (Coblentz and Richardson, 1996; Coblentz and Sandiford, 1994). On a global scale, the work of Osei Tutu et al. (2018), Steinberger et al. (2001) and Bird (1998) investigated the impact of mantle convection on the lithospheric stress field. These models provide a first-order understanding of the stress pattern that is observed in the WSM, but the local variability cannot be explained due to resolution limits of global models as well as the missing vertical rheological stratification of the crust that is also an important ingredient to quantify in particular stress mag- 


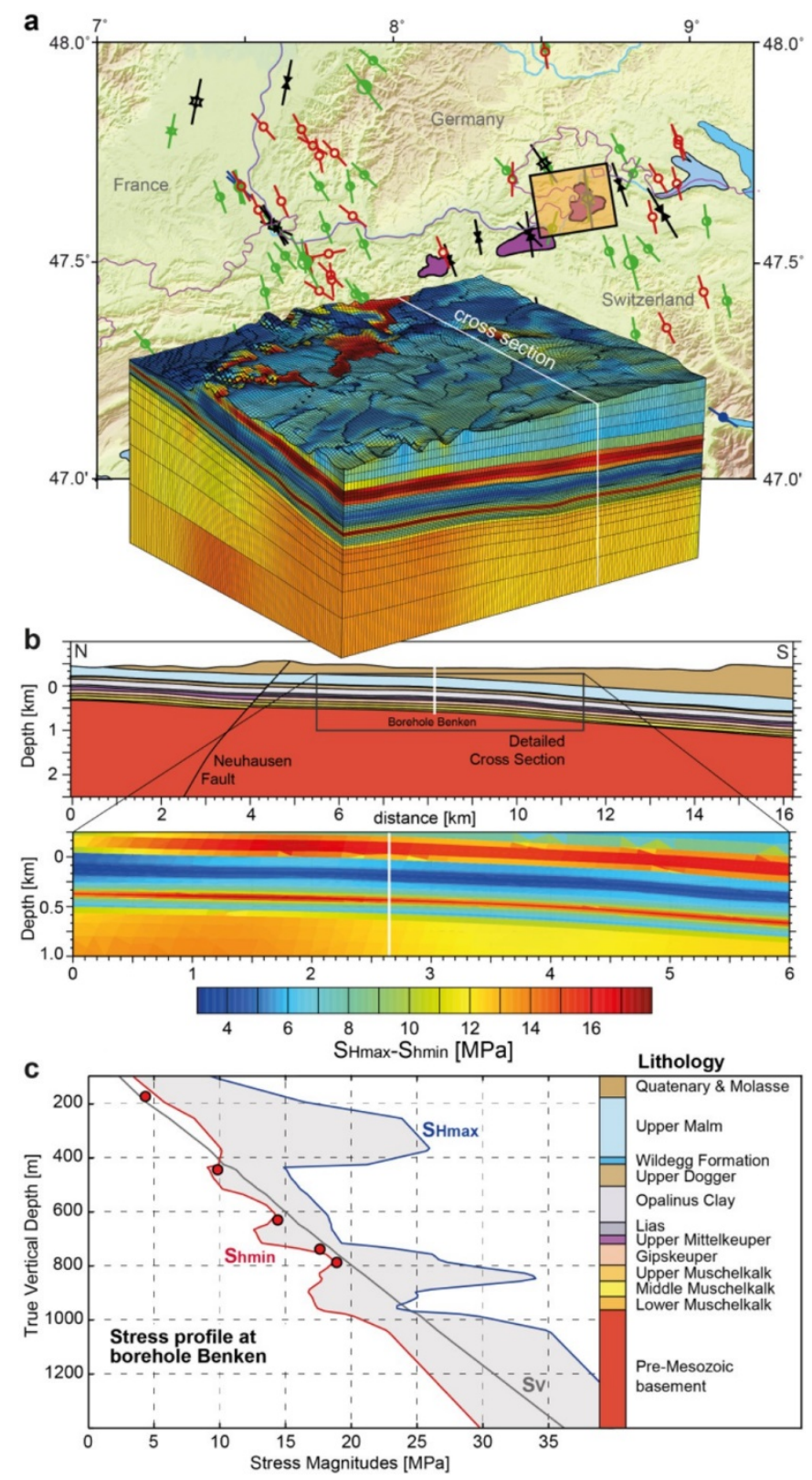

Figure 8. a) Stress map of northern Switzerland with locations of potential deep geological repository for high-level radioactive waste (purple areas) and extent of the model area (yellow square). 3-D model shows the $20 \times 20 \times 3 \mathrm{~km} 3$ model volume with the discretization into finite elements (two-fold vertical exaggeration). Colours show the modelled difference between maximum and minimum horizontal stresses $S_{\text {Hax }}-S_{\text {hmin }}$ (Hergert et al., 2015). White lines indicate the location of the cross section. b) Upper figure shows on a NS cross section the lithological layers within the sediment sequence of the Alpine Foreland that are represented in the model. Lower figure shows the model results of horizontal stress difference $S_{H \max }-S_{h \min }$. c) Modelled magnitudes of $S_{V}, S_{H \max }$ and $S_{h \min }$ along a vertical borehole profile. Red dots show measurements of the $S_{\text {hmin }}$ magnitude in clay rich layers from hydraulic fracturing tests (NAGRA, 2001) that were used for model calibration. Grey shaded area denotes the horizontal stress difference $S_{\text {Hax }}-S_{\text {hmin }}$. Note that this is only one simulation amongst a wide range of possible solutions that fit the constraints $\left(S_{h m i n}\right.$ magnitudes, $S_{\text {Hax }}$ orientation, and stress regime) in this region as well.

nitudes (Bürgmann and Dresen, 2008; Cloetingh et al., 2013; Hergert et al., 2015; Warpinski, 1989).

\section{Examples of stress tensor rotations on regional scales}

The substantial data record increase in the WSM database release 2016 enables us to investigate the rotation of the $S_{\text {Hmax }}$ orientation on regional scales from 50 to $500 \mathrm{~km}$ in a number of areas. As examples we chose Eastern Australia (Section 4.1) and the south-central part of the U.S. (Section 4.2) given the large increases in borehole data in these regions (Alt II and Zoback, 2017; Lund Snee and Zoback, 2016; Rajabi et al., 2016a, 2017b). Other areas with similar rotations can be found in areas such as Northern Germany (Heidbach et al., 2007), southern Africa (Bird et al., 2006), China (Hu et al., 2017) and in other parts of Australia (Rajabi et al., 2017b, 2017c).

\subsection{Stress pattern in Eastern Australia}

Using the global analysis displayed in Fig. 4a (fixed search radius of $r=500 \mathrm{~km}$ ), the mean $S_{\text {Hmax }}$ orientation rotates from NE-SW to NW-SE from the northern to southern areas of Eastern Australia. Zooming into Eastern Australia and using a fixed search radius of $250 \mathrm{~km}$, reveals a more diverse mean $S_{H \max }$ orientation pattern with a gradual clockwise rotation $>100^{\circ}$ from a N-S orientation in northern Queensland to a NW-SE orientation in Victoria (Fig. 6a). This stress pattern changes on wave-lengths of approximately $500 \mathrm{~km}$. This is smaller than the general plate-wide scale stress pattern observed in North and South America where the mean $S_{H \max }$ orientation shows only changes of $20-30^{\circ}$ over thousands of kilometres (Hurd and Zoback, 2012; Reiter et al., 2014; Zoback and Zoback, 1991; Zoback and Zoback, 1980, 1989). The mean $S_{\text {Hmax }}$ pattern is even more diverse if a fixed search radius of $75 \mathrm{~km}$ is used, with rotations of $50-60^{\circ}$ within $70 \mathrm{~km}$ observed in areas such as the Bowen and Surat basins of SE Queensland (Fig. 6b).

\subsection{Stress pattern in south-central U.S.}

Using the global analysis displayed in Fig. 4a (fixed search radius of $r=500 \mathrm{~km}$ ), the mean $S_{\text {Hmax }}$ orientation rotates from E-W in southern Oklahoma $30-40^{\circ}$ counterclockwise to a NE orientation in southern Texas. With a lower fixed search radius of $250 \mathrm{~km}$ for this area the stress pattern becomes more diverse rotating $60-80^{\circ}$ counterclockwise from North to South (Fig. 7a). Zooming into a smaller region (Fig. 7b) and using a smaller fixed search radius $(r=75 \mathrm{~km})$ the variability increases and a $40^{\circ}$ rotation of the mean $S_{\text {Hmax }}$ orientation is observed within 70 $\mathrm{km}$ which is similar to the rotation observed in New South Wales, Australia (Fig. 6a). In a recent paper, Lund Snee and Zoback (2018) provide even more data for the south-eastern region of the state New Mexico. With this additional stress information, which is not part of the WSM database release 2016, they reveal that the $S_{H \max }$ orientation rotates in the Delaware basin from a NS-orientation in New 
Mexico by $150^{\circ}$ clockwise in western Texas.

In analogy to Australia the plate-wide stress model of North America by Humphreys and Coblentz (2007) was able to match the first-order large-scale stress pattern, but local variabilities were not resolved at that time and not the focus of their paper. However, these newly revealed large rotations of the $S_{H \max }$ orientation deliver new constraints for the calibration of geomechanical-numerical models.

The observed large rotations of the $S_{H \max }$ orientation within $<100 \mathrm{~km}$ indicate that plate-wide, regional and local stress sources compensate each other and, most probably, lead to a horizontal stress state that is close to isotropic. In this case relatively small local stress sources can rotate horizontal the stress tensor (Sonder, 1990; Zoback, 1992). To quantify the relative importance of far-field stresses from plate boundary forces in comparison to stresses that originate from regional and local sources 3-D geomechanical-numerical modelling is essential (Chéry et al., 2004; Fischer and Henk, 2013; Gunzburger and Magnenet, 2014; Henk, 2005; Hergert et al., 2015; Humphreys and Coblentz, 2007; Reiter and Heidbach, 2014; Ziegler et al., 2016a).

In general, we observe the trend that in some intra-plate regions more $S_{H \max }$ rotations on small-scale are detected with increasing resolution of the stress field. However, this is not the case in foreland basins. The increase of data in the Alberta basin (Reiter et al., 2014), the Swiss Molasse (Heidbach and Reinecker, 2013), the Alpine Foreland (Reinecker et al., 2010), or in the southern Andes (Guzmán and Cristallini, 2009) did not change the stress pattern at all, but confirmed the earlier mean $S_{H \max }$ orientation trends and the long wave-length $S_{H \max }$ pattern. Intraplate settings with little topography seem to be more prone for $S_{\text {Hmax }}$ rotations controlled by local stress sources acting on 10-100 $\mathrm{km}$ scale. Here the horizontal differential stresses are probably smaller compared to areas where nearby topography imposes higher $S_{H \max }$ magnitudes due to gravitational load leading to a higher horizontal differential stress $S_{H \max }$ $S_{\text {hmin }}$. Thus, local stress perturbations in these regions are not large enough to rotate the horizontal stresses significantly. At locations where the magnitudes of the local stress perturbation is known, this kind of analysis offers the potential to estimate the magnitudes of the global to regional stresses (Sonder, 1990; Ziegler et al., 2017; Zoback, 1992).

\section{Perspectives of the WSM project}

\subsection{From point-wise data towards a continuous 3-D stress field}

A key challenge for the WSM project is to derive a continuous description of the 3-D stress tensor from the pointwise, sparse and incomplete stress data provided by the WSM database. Fig. 8 displays an example for Northern Switzerland in the Alpine foreland where a 3-D geomechanical-numerical model has been set up for a potential deep geological repository site for high-level radioactive waste (Hergert et al., 2015). The model is calibrated with measurements of the $S_{\text {hmin }}$ magnitude data in clay rich layers (NAGRA, 2001) as shown in Fig. 8c. The results indicate that the stress orientations do not change with depth, but that horizontal stress magnitudes vary significantly due to the rock strength contrast in the sedimentary sequence. The key limitation of such models, in terms of reliability, is the lack of $S_{H \max }$ stress magnitude data for a robust model calibration. The results presented in Fig. 8 are only one simulation amongst a wide range of other possibilities that also match equally well the $S_{\text {hmin }}$ stress magnitude data, the stress regime and the $S_{\text {Hmax }}$ orientation in Northern Switzerland.

Another fundamental problem of small-scale models in the order of $20 \mathrm{~km}$ or less is, that in a given area often very little or even no information on the crustal stress field is a priori available. Furthermore, the stress field information is mainly limited to $S_{H \max }$ orientation data which is not sufficient for model calibration of the stress magnitudes unless significant stress rotations are reported. To overcome this, a multistage approach has been developed and tested in the Alpine foreland (Ziegler et al., 2016a). Here a larger scale model, for which stress magnitude data are available, is used to derive initial and boundary conditions for a reservoir scale model.

Forward modelling of the total 3-D in-situ stress tensor is not only essential to study the relative importance of stress sources, but it is also necessary to assess the 'criticality' of the contemporary crustal stress field, i.e. how close the in-situ stress state is from failure. This information is e.g. needed to assess how much man-made induced stress changes in the underground due to excavation (tunnels, caverns) fluid injection/production, storage of waste, fluids and energy is possible without a violation of the integrity of sealing layers and faults. Furthermore, the initial in-situ stress state is essential to assess how close a given fault is from failure (fault re-activation potential), to plan a safe borehole trajectory or in which direction hydraulically-induced fractures will propagate (Altmann et al., 2014; Bell, 1996b; Müller et al., 2018; Walsh and Zoback, 2016).

\subsection{Fourth phase of the WSM project (2017-2025)}

The key new activity for the 4th phase of the WSM (from 2017 to 2025) is to extend the WSM database with stress magnitude data. This information is essential for the calibration of geomechanical-numerical models that describe the contemporary 3-D in-situ stress state. However, we will also continue and intensify the compilation of stress orientation information to further resolve $S_{H \max }$ rotations. These rotations will also provide key information to study the relative impact of far-field and regional to local stress sources. Furthermore, there are still large regions where very little or even no data are available.

Another challenge is to capture temporal stress changes and horizontal stress tensor rotations which are 
observed at various scales. For example, at the tectonic plate boundaries the stress changes occur due to tectonic loading in the inter-seismic phase and from stress drops of major earthquakes (Hardebeck, 2017). Here the rapid increase of data from satellite geodesy in data density and length of high-quality timeseries provide potential to detect temporal stress changes (Heidbach and Ben-Avraham, 2007; Kreemer et al., 2014; Townend and Zoback, 2006). At reservoir scales, significant stress tensor rotations due to injection or production of fluids have been observed and modelled (Martinez-Garcon et al., 2013; Müller et al., 2018; Ziegler et al., 2017). This might become a major issue since massive storage of energy, waste or $\mathrm{CO}_{2}$ is probably a key building block for the challenges that we face in the transition from fossil to renewable energy in the next decades.

On a technical level we aim to change our database release policy. Instead of compiling every 6-8 years a new WSM database we intend to update the data set several times per year to account for the steady and increasing influx of new data that we experienced in past few years. We will announce these new releases in our WSM technical report series where new data and changes of the WSM database will be described. Both, each new release and the accompanying WSM technical report will get a digital object identifier to be able to track down the database version that has been used.

These are the challenges for the ongoing 4th phase (2017-2025) of the WSM project. In particular the database extension by stress magnitudes can only be accomplished with a joint effort of the international scientific community from different disciplines and industry partners and we will soon call for participation to accomplish this ambitious goal.

\section{Acknowledgement}

We would like to thank Tim Horscroft (Review Papers Coordinator of Elsevier) and Rob Govers (Editor-in-Chief of Tectonophysics) for inviting us to contribute this paper to Tectonophysics. We also would like to thank anonymous reviewers who helped us to increase the quality of the paper. Support of the WSM project was provided by the International Lithosphere Program, the Heidelberg Academy of Sciences and Humanities and the Helmholtz Centre Potsdam, GFZ German Research Centre for Geosciences. We also acknowledge the following individual scientists who contributed significantly to the success of the WSM project in one way or the either in the past 30 years: Adams, J.; Ágústsson, K.; Alt, R.; Al-Zoubi, A.S.; Andreoli, M.; Árnadóttir, S.; Ask, D.; Ask, M.; Assumpcao, M.; Babyyev, G.; Badawy, A.; Bailey, A.; Balfour, N.; Baptie, B.; Barr, M.; Barth, A.; Batchelor, T.; Becker, A.; Bell, S.; Bergerat, F.; Bergman, E.; Blümling, P.; Bohnhoff, M.; Bonjer, K.-P.; Bosworth, W.; Bratli, R.; Brereton, R.; Brudy, M.; Bungum, H.; Chatterjee, R.; Colmenares, L.; Connolly, P.; Cornet, F.; Custodio, S.; Deichmann, N.; Delvaux, D.; Denham, D.; Ding, J.; Djotsa, V.; Doeveny, P.; Enever, J.; Feijerskov, M.; Finkbeiner, T.; Fleckenstein, P.; Gay, N.; Gerner, P.; Giger, S.; Gough, D.I.; Gowd, T.N.; Grasso, M.; Gregersen, S.; Grünthal, G.; Gupta, H.; Guzmán, C.; Gvishiani, A.; Haimson, B.; Hanssen, T.H.; Hauk, C.; Hergert, T.; Hersir, G.P.; Hickman, S.; Hillis, Höhne, J; R.; Horvath, F.; Hu, X.; Jacob, K.; Jarosinski, M.; Jianmin, D.; Jurado, M.J.; King, R.; Kingdon, A.; Kjorholt, H.; Klein, R.; Knoll, P.; Kropotkin, P.; Kurfeß, D.; Larsen, R.; Lindholm, C.; Logue, A.; López, A.; Lund, B.; Lund-Snee, J.; Magee, M.; Mariucci, M.T.; Marschall, I.; Mastin, M.; Maury, V.; Mercier, J.; Mildren, S.; Montone, P.; Mularz-Pussak, M.; Negut, M.; Oncescu, M.C.; Paquin, C.; Pavoni, N.; Pierdominici, S.; Pondrelli, A.; Ragg, S.; Rajendran, K.; Reynolds, S.; Röckl, T.; Roth, F.; Rummel, F.; Schmitt, D.; Schoenball, M.; Sebrier, M.; Sherman,
S.; Sperner, B.; Stephansson, O.; Stromeyer, D.; Suarez, G.; Suter, M.; Tolppanen, P.; Townend, J.; Tsereteli, N.; Udias, A.; van Dalfsen, W.; van Eijs, R.; Van-Kin, L.; Vietor, T.; Williams, J.; Wiprut, D.; Wolter, K.; Xu, Z.H.; Yunga, S.; Zhonghuai, X.; Zhizhin, M.

Finally, we also want to thank cordially any contributor of data, especially the companies and state organisations that contributed their data.

\section{Appendix A}

Supplementary data to this article can be found online at https:// doi.org/10.1016/j.tecto.2018.07.007.

\section{References}

Alt II, R.C., Zoback, M.D., 2017. In situ stress and active faulting in Oklahoma. Bull. Geol. Soc. Am. 107, 216-228. https://doi.org/10.1785/0120160156.

Altmann, J.B., Müller, B., Müller, T., Heidbach, O., Tingay, M., Weißhardt, A., 2014. Pore pressure stress coupling in 3D and consequences for reservoir stress states and fault reactivation. Geothermics 52, 195-205. https://doi.org/10.1016/j.geothermics. 2014.01.004.

Amadei, B., Stephansson, O., 1997. Rock Stress and its Measurements. Chapman and Hall, New York.

Amante, C., Eakins, B.W., 2009. ETOP01 1 arc-minute global relief model procedures, data sources and analysis. In: National Geophysical Data Center, N. (Ed.), NOAA Technical Memorandum NESDIS NGDC-24, . https://doi.org/10.7289/V5C8276M.

Assumpcao, M., Sacek, V., 2013. Intra-plate seismicity and flexural stresses in central Brazil. Geophys. Res. Lett. 40, 487-491. https://doi.org/10.1002/grl.50142.

Assumpcao, M., Dias, F.L., Zevallos, I., Naliboff, J.B., 2016. Intraplate stress field in South America from earthquake focal mechanisms. S. Am. Earth Sci. 71, 1-18. https://doi. org/10.1016/j.jsames.2016.07.005.

Bell, J.S., 1996a. In situ stresses in sedimentary rocks (part 1): measurement techniques. Geosci. Can. 23, 85-100.

Bell, J.S., 1996b. In situ stresses in sedimentary rocks (part 2): applications of stress measurements. Geosci. Can. 23, 135-153.

Bell, J.S., Gough, D.I., 1979. Northeast-southwest compressive stress in Alberta: evidence from oil wells. Earth Planet. Sci. Lett. 45, 475-482.

Bird, P., 1998. Testing hypotheses on plate-driving mechanisms with global lithosphere models including topography, thermal structure, and faults. J. Geophys. Res. 103 10115-10129.

Bird, P., 2003. An updated digital model for plate boundaries. Geochem. Geophys. Geosyst. 4. https://doi.org/10.1029/2001GC000252.

Bird, P., Ben-Avraham, Z., Schubert, G., Andreoli, M., Viola, G., 2006. Patterns of stress and strain-rate in southern Africa. J. Geophys. Res. 111. https://doi.org/10.1029/ 2005JB003882.

Brown, E.T., Hoek, E., 1978. Trends in the relationship between in situ stresses and depth Int. J. Rock Mech. Min. Sci. Geomech. Abstr. 15, 211-225.

Brudy, M., Zoback, M.D., Fuchs, K., Rummel, F., Baumgärtner, J., 1997. Estimation of the complete stress tensor to $8 \mathrm{~km}$ depth in the KTB scientific drill holes: implications for the crustal strength. J. Geophys. Res. 102, 18453-18475.

Bürgmann, R., Dresen, G., 2008. Rheology of the lower crust and upper mantle: evidence from rock mechanics, geodesy and field observations. Ann. Rev. Earth Planet. Sci. 36, 531-567.

Célérier, B., 2010. Remarks on the relationship between the tectonic regime, the rake of the slip vectors, the dip of the nodal planes, and the plunges of the $\mathrm{P}, \mathrm{B}$, and $\mathrm{T}$ axes of earthquake focal mechanisms. Tectonophysics 482, 42-49. https://doi.org/10.1016/ j.tecto.2009.03.006

Chéry, J., Zoback, M.D., Hickman, S.H., 2004. A mechanical model of the San Andreas fault and the SAFOD Pilot Hole stress measurements. Geophys. Res. Lett. 31. https:// doi.org/10.1029/2004GL019521

Cloetingh, S., Wortel, R., 1985. Regional stress field of the Indian plate. Geophys. Res. Lett. 77-80

Cloetingh, S., Wortel, R., 1986. Stress in the Indo-Australian plate. Tectonophysics 132, 4967.

Cloetingh, S., Burov, E., Francois, T., 2013. Thermo-mechanical controls on intra-plate deformation and the role of plume-folding interactions in continental topography. Gondwana Res. 24, 815-837. https://doi.org/10.1016/j.gr.2012.11.012.

Coblentz, D., Richardson, R.M., 1995. Statistical trends in the intraplate stress field. J. Geophys. Res. 100, 20245-20255. https://doi.org/10.1029/95JB02160.

Coblentz, D., Richardson, R.M., 1996. Analysis of the South American intraplate stress field. J. Geophys. Res. 101, 8643-8657.

Coblentz, D.D., Sandiford, M., 1994. Tectonic stresses in the African plate: constraints on the ambient lithospheric stress state. Geology 22, 831-834.

Coblentz, D.D., Sandiford, M., Richardson, R.M., Zhou, S., Hillis, R., 1995. The origins of the intraplate stress field in continental Australia. Earth Planet. Sci. Lett. 133, 299-309.

Cornet, F.H., Röckel, T., 2012. Vertical stress profiles and the significance of "stress decoupling". Tectonophysics 581, 193-205. https://doi.org/10.1016/j.tecto.2012.01. 020. Davis, J.C., 1986. Statistics and Data Analysis in Geology, 2nd ed. John Wiley, New York. Dyksterhuis, S., Albert, R.A., Müller, R.D., 2005. Finite-element modelling of contemporary and palaeointraplate stress using ABAQUS. Comp. Geosci. 31, 297-307.

Dziewonski, A.M., Chou, T.-A., Woodhouse, J.H., 1981. Determination of earthquake source parameters from waveform data for studies of global and regional seismicity. J. Geophys. Res. 86, 2825-2852. https://doi.org/10.1029/JB086iB04p02825. Engelder, T., 
1992. Stress Regimes in the Lithosphere. Princeton, NJ.

Fischer, K., Henk, A., 2013. A workflow for building and calibrating 3-D geomechanical models - a case study for a gas reservoir in the North German Basin. Solid Earth 53555357. https://doi.org/10.5194/se-5194-5347-2013.

Fjaer, E., Holt, R., Horsrud, P., Raaen, A., Risnes, R., 2008. Petroleum Related Rock Mechanics, 2nd ed. Elsevier, Amsterdam.

Fjeldskar, W., 1995. Viscosity and thickness of the asthenosphere detected from the Fennoscandian uplift. Earth Planet. Sci. Lett. 126, 399-410.

Gaucher, E., Schoenball, M., Heidbach, O., Zang, A., Fokker, P., van Wees, J.-D., Kohl, T., 2015. Induced seismicity in geothermal reservoirs: a review of forecasting approaches. Renew. Sust. Energ. Rev. 52,11473-11490. https://doi.org/10.11016/j. res.12015.11408.11026. (114).

Gölke, M., Coblentz, D., 1996. Origins of the European regional stress field. Tectonophysics 266, 11-24.

Gripp, A.E., Gordon, R.G., 2002. Young tracks of hotspots and current plate velocities. Geophys. J. Int. 150, 321-361. https://doi.org/10.1046/j.1365-246X.2002.01627.x.

Grünthal, G., Stromeyer, D., 1986. Stress pattern in Central Europe and adjacent areas. Gerlands Beitr. Geophysik 95, 443-452.

Grünthal, G., Stromeyer, D., 1992. The recent crustal stress field in Central Europe: trajectories and finite element modeling. J. Geophys. Res. 97, 11805-11820.

Gunzburger, Y., Magnenet, V., 2014. Stress inversion and basement-cover stress transmission across weak layers in the Paris basin, France. Tectonophysics 617, 44-57.

Guzmán, C., Cristallini, E., 2009. Contemporary stress orientations from borehole breakouts analysis in the southernmost flat-slab boundary Andean retroarc $\left(32^{\circ} 44^{\prime}\right.$ and $33^{\circ} 40^{\prime}$ S). J. Geophys. Res. 114. https://doi.org/10.1029/2007JB005505.

Guzmán, C., Cristallini, E., Bottesi, G. 2007. Contemporary stress orientations in the Andean retroarc between $34^{\circ} \mathrm{S}$ and $39^{\circ} \mathrm{S}$ from borehole breakout analysis. Tectonics 26 . https://doi.org/10.1029/2006TC001958.

Haimson, B.C., Cornet, F.H., 2003. ISRM suggested methods for rock stress estimation part 3: hydraulic fracturing (HF) and/or hydraulic testing of pre-existing fractures (HTPF). Int. J. Rock. Mech. 40, 1011-1020.

Hakimhashemi, A., Schoenball, M., Heidbach, O., Zang, A., Grünthal, G., 2014a. Forward modelling of seismicity rate changes in georeservoirs with a hybrid geomechanicalstatistical prototype model. Geothermics 52, 185-194. https://doi.org/10.1016/j. geothermics.2014.01.001.

Hakimhashemi, A., Yoon, J.S., Heidbach, O., Zang, A., Grünthal, G., 2014b. Forward induced seismic hazard assessment: application to a synthetic seismicity catalogue from hydraulic stimulation modelling. J. Seismol. 18, 671-680. https://doi.org/10.1007/s10950-014-9439-y.

Hardebeck, J.L., 2017. The spatial distribution of earthquake stress rotations following large subduction zone earthquakes. Earth Planet. Space 69 https://doi.org/10.1186/s40623-017-0654-y.

Hardebeck, J.L., Okada, T., 2018. Temporal stress changes caused by earthquakes: a review. J. Geophys. Res. 123, 1350-1365. https://doi.org/10.1102/2017JB014617.

Harris, R.A., 1998. Introduction to special section: stress triggers, stress shadows, and implications for seismic hazard. J. Geophys. Res. 103, 24347-24358.

Hast, N., 1973. Global measurements of absolute stress. Philos. Trans. R. Soc. Lond. 274, 409-419.

Heidbach, O., Ben-Avraham, Z., 2007. Stress evolution and seismic hazard of the Dead Sea fault system. Earth Planet. Sci. Lett. 257, 299-312.

Heidbach, O., Höhne, J., 2008. CASMI - a tool for the visualization of the World Stress Map data base. Comp. Geosci. 34, 783-791. http://dx.doi.org/1016/j.cageo.2007.06. 004.

Heidbach, O., Reinecker, J., 2013. Analyse des rezenten Spannungsfeldes der Nordschweiz NAGRA Arb. Ber. NAB 12-05. NAGRA, Wettingen, pp. 120

Heidbach, O., Ziegler, M.O., 2018. Smoothed Global Stress Maps Based on the World Stress Maps Database Release 2016. GFZ Data Services. https://doi.org/10.5880/ WSM.2018.002.

Heidbach, O., Barth, A., Connolly, P., Fuchs, F., Müller, B., Reinecker, J., Sperner, B., Tingay, M., Wenzel, F., 2004. Stress maps in a minute: the 2004 world stress map release. EOS Trans. 85, 521-529.

Heidbach, O., Reinecker, J., Tingay, M., Müller, B, Sperner, B., Fuchs, K., Wenzel, F., 2007. Plate boundary forces are not enough: second- and third-order stress patterns highlighted in the World Stress Map database. Tectonics 26. https://doi.org/10.1029/2007TC002133.

Heidbach, O., Iaffaldano, G., Bunge, H.-P., 2008. Topography growth drives stress rotations in the Central Andes - observations and models. Geophys. Res. Lett. 35. https:// doi.org/10.1029/2007GL032782.

Heidbach, O., Tingay, M., Barth, A., Reinecker, J., Kurfeß, D., Müller, B., 2010. Global crustal stress pattern based on the World Stress Map database release 2008.

Tectonophysics 482, 3-15. https://doi.org/10.1016/j.tecto.2009.07.023.

Henk, A., 2005. Pre-drilling prediction of the tectonic stress field with geomechanical models. First Break 23, 53-57.

Henk, A., 2008. Perspectives of geomechanical reservoir models - why stress is important. Eur. Mag. 4, 1-5.

Hergert, T., Heidbach, O., 2011. Geomechanical model of the Marmara Sea region - II. 3-D contemporary background stress field. Geophys. J. Int. 185, 1090-1102. https://doi. org/10.1111/j.1365-246X.2011.04992.x

Hergert, T., Heidbach, O., Reiter, K., Giger, S., Marschall, P., 2015. Stress field sensitivity analysis in a sedimentary sequence of the Alpine foreland, northern Switzerland

Solid Earth 6, 533-552. https://doi.org/10.5194/se-6-533-2015.

Hillis, R.R., Reynolds, S.D., 2000. The Australian stress map. J. Geol. Soc. 157, 915-921.

Hillis, R.R., Reynolds, S.D., 2002. In situ stress field of Australia. Geol. Soc. Aust. Publ. 22, 43-52.

Hu, X., Zang, A., Heidbach, O., Cui, X., Xie, F., Chen, J., 2017. Crustal stress pattern in China and its adjacent areas. J. Asian Earth Sci. 149, 20-28. https://doi.org/10.1016/j.jseaes.2017.07.005.

Humphreys, E.D., Coblentz, D.D., 2007. North American dynamics and western U.S. tectonics. Rev. Geophys. 45. https://doi.org/10.1029/2005RG000181.
Hurd, O., Zoback, M.D., 2012. Intraplate earthquakes, regional stress and fault mechanisms in the Central and Eastern U.S. and Southeastern Canada. Tectonophysics 581, 182-192. https://doi.org/10.1016/j.tecto.2012.04.002.

Jaeger, J.C., Cook, N.G.W., Zimmermann, R.W., 2007. Fundamentals of Rock Mechanics, 4th ed. Blackwell Publishing, Oxford.

King, G.C.P., Stein, R.S., Lin, J., 1994. Static stress changes and the triggering of earthquakes. Bull. Seismol. Soc. Am. 84, 935-953.

Kingdon, A., Fellgett, M.W., Williams, D.O., 2016. Use of borehole imaging to improve understanding of the in-situ stress orientation of Central and Northern England and its implications for unconventional hydrocarbon resources. Mar. Pet. Geol. 73, 1-20. https://doi.org/10.1016/j.marpetgeo.2016.02.012.

Konstantinovskaya, E., Malo, M., Castillo, D.A., 2012. Present-day stress analysis of the St. Lawrence Lowlands sedimentary basin (Canada) and implications for caprock integrity during $\mathrm{CO}_{2}$ injection operations. Tectonophysics 518-521, 119-137.

Kreemer, C., Blewitt, G., Klein, E.C., 2014. A geodetic plate motion and Global Strain Rate Model. Geochem. Geophys. Geosyst. 15. https://doi.org/10.1002/2014GC005407.

Kuckshinrichs, W., Hake, J.-F., 2015. Carbon Capture, Storage and Use. Springer, Berlin. https://doi.org/10.1007/978-3-319-11943-4

Ljunggren, C., Chang, Y., Janson, T., Christiansson, R., 2003. An overview of rock stress measurement methods. Int. J. Rock. Mech. 40, 975-989.

Lund Snee, J.-E., Zoback, M.D., 2016. State of stress in Texas: implications for induced seismicity. Geophys. Res. Lett. 43, 10208-10214. https://doi.org/10.1002/ 2016GL070974.

Lund Snee, J.-E., Zoback, M., 2018. State of stress in the Permian Basin, Texas and New Mexico: implications for induced seismicity. Lead. Edge 127-136. https://doi.org/10 1190/tle37020127.1.

Lund, B., Zoback, M.D., 1999. Orientation and magnitude of in situ stress to $6.5 \mathrm{~km}$ depth in the Baltic Shield. Int. J. Rock Mech. Min. Sci. 36, 169-190.

Mardia, K.V., 1972. Statistics of Directional Data: Probability and Mathematical Statistics. Academic Press, London.

Martens, S., Hangx, S., Juhlin, C., Kühn, M., Kempka, T., 2017. Energy, resources and the environment: meeting the challenges of the future. Energy Procedia 125, 1-5. https://doi.org/10.1016/j.egypro.2017.08.301.

Martinez-Garcon, P., Bohnhoff, M., Kwiatek, G., Dresesn, G., 2013. Stress tensor changes related to fluid injection at The Geysers geothermal field, California. Geophys. Res. Lett. 118, 2596-2601. https://doi.org/10.1002/grl.504328.

Maury, J., Cornet, F.H., Dorbath, L., 2013. A review of methods for determining stress fields from earthquake focal mechanisms: application to the Sierentz 1980 seismic crisis (Upper Rhine graben). Bull. Soc. Geol. Fr. 184, 319-334.

McKenzie, D., 1969. The relation between fault plane solutions for earthquakes and the directions of the principal stresses. Bull. Seismol. Soc. Am. 59, 591-601.

Minster, J.B., Jordan, T.H., 1978. Present-day plate motion. J. Geophys. Res. 83, 53315354.

Montone, P., Mariucci, M.T., 2016. The new release of the Italian contemporary stress map. Geophys. J. Int. 205, 1525-1531. https://doi.org/10.1093/gji/ggw100.

Morris, A., Ferril, D.A., Henderson, D.B., 1996. Slip-tendency analysis and fault reactivation. Geology 24, 275-278.

Müller, B., Zoback, M.L., Fuchs, K., Mastin, L., Gregersen, S., Pavoni, N., Stephansson, 0. Ljunggren, C., 1992. Regional patterns of tectonic stress in Europe. J. Geophys. Res. 97, 11783-11803. https://doi.org/10.1029/91JB01096.

Müller, B., Wehrle, V., Hettel, S., Sperner, B., Fuchs, F., 2003. A new method for smoothing oriented data and its application to stress data. In: Ameen, M. (Ed.), Fracture and Insitu Stress Characterization of Hydrocarbon Reservoirs. Geological Society, London, pp. 107-126

Müller, B., Schilling, F., Röckel, T., Heidbach, O., 2018. Induced seismicity in reservoirs: stress makes the difference. Erdöl Erdgas Kohle 134, 33-37.

NAGRA, 2001. Sondierungsbohrung Benken Untersuchungsbericht, NAGRA Tech. Ber. NTB 00-01, Wettingen. pp. 273 (S)

Oglesby, D.D., Mai, P.M., 2012. Fault geometry, rupture dynamics and ground motion from potential earthquakes on the North Anatolian Fault under the Sea of Marmara. Geophys. J. Int. 188, 1071-1087. https://doi.org/10.1111/j.1365-246X.2011. 05289.x.

Osei Tutu, A., Steinberger, B., Sobolev, S.V., Rogozhina, I., Popov, A.A., 2018. Effects of upper mantle heterogeneities on the lithospheric stress field and dynamic topography. Solid Earth 9, 649-668. https://doi.org/10.5194/se-9-649-2018.

Pierdominici, S., Heidbach, 0., 2012. Stress field of Italy - mean stress orientation at different depths and wave-length of the stress pattern. Tectonophysics 532-535, 301311. https://doi.org/10.1016/j.tecto.2012.02.018.

Plumb, R.A., Hickman, S., 1985. Stress-induced borehole enlargement: a comparison between the four-arm dipmeter and the borehole televiewer in the Auburn geothermal well. J. Geophys. Res. 90, 5513-5521.

Pusch, R., 2008. Geological Storage of Radioactive Waste. Springer, Berlin.

Rajabi, M., Tingay, M., Heidbach, O., 2016a. The present-day stress field of New South Wales, Australia. Aust. J. Earth Sci. 63, 1-21. https://doi.org/10.1080/08120099. 2016.1135821.

Rajabi, M., Ziegler, M., Tingay, M., Heidbach, O., Reynolds, S., 2016b. Contemporary tectonic stress pattern of the Taranaki Basin, New Zealand. J. Geophys. Res. 121, 60536070. https://doi.org/10.1002/2016JB013178.

Rajabi, M., Heidbach, O., Tingay, M., Reiter, K., 2017a. Prediction of the present-day stress field in the Australian continental crust using 3D geomechanical-numerical models. Aust. J. Earth Sci. 64, 435-454. https://doi.org/10.1080/08120099.2017. 1294109. Rajabi, M., Tingay, M., Heidbach, O., Hillis, R., Reynolds, S., 2017b. The present-day stress field of Australia. Earth-Sci. Rev. 168, 165-189. https://doi.org/10.1016/j. earscirev.2017.04.003.

Rajabi, M., Tingay, M., King, R., Heidbach, O., 2017c. Present-day stress orientation in the Clarence-Moreton Basin of New South Wales, Australia: a new high density dataset reveals local stress rotations. Basin Res. 29, 622-640. https://doi.org/10.1111/bre. 12175.

Ranalli, G., Chandler, T.E., 1975. The stress field in the upper crust as determined from in situ measurements. Geol. Rundsch. 64, 653-674. 
Reinecker, J., Tingay, M., Müller, B., Heidbach, O., 2010. Present-day stress orientation in the Molasse Basin. Tectonophysics 462. https://doi.org/10.1016/j.tecto.2009.1007. 1021.

Reiter, K., Heidbach, 0., 2014. 3-D geomechanical-numerical model of the contemporary crustal stress state in the Alberta Basin (Canada). Solid Earth 5, 1123-1149. https:// doi.org/10.5194/se-5-1123-2014.

Reiter, K., Heidbach, O., Schmitt, D., Moeck, I., Ziegler, M., Hauck, C., 2014. Crustal stress field pattern of Canada. Tectonophysics 636, 111-124. https://doi.org/10.1016/j.tecto.2014.08.006.

Reiter, K., Heidbach, O., Müller, B., Reinecker, J., Röckel, T., 2016. In: Services, G.D. (Ed.), Stress Map Germany 2016, 1st ed. GFZ German Research Centre for Geosciences, Potsdam. https://doi.org/10.5880/WSM.Germany2016_en.

Reynolds, S.D., Coblentz, D., Hillis, R.R., 2002. Tectonic forces controlling the regional intraplate stress field in continental Australia: results from new finite element modelling. J. Geophys. Res. 107 (2131). https://doi.org/10.1029/2001JB000408.

Richardson, R.M., 1992. Ridge forces, absolute plate motions, and the intraplate stress field. J. Geophys. Res. 97, 11739-11748.

Richardson, R.M., Solomon, S.C., Sleep, N.H., 1979. Tectonic stress in plates. Rev. Geophys. 17, 981-1019.

Roth, F., Fleckenstein, P., 2001. Stress orientations found in north-east Germany differ from the West European trend. Terra Nova 13, 289-296.

Sbar, M.L., Sykes, L.R., 1973. Contemporary compressive stress and seismicity in eastern North America, an example of intraplate tectonics. Geol. Soc. Am. Bull. 84, 1861-1882.

Schmitt, D.R., Currie, C.A., Zhang, L., 2012. Crustal stress determination from boreholes and rock cores: fundamental principles. Tectonophysics 580, 1-26. https://doi.org/ 10.1016/j.tecto.2012.08.029.

Schoenball, M., Davatzes, N.C., 2017. Quantifying the heterogeneity of the tectonic stress field using borehole data. J. Geophys. Res. 122, 1-20. https://doi.org/10.1002/ 2017JB014370.

Schoenball, M., Walsh, F.R., Weingarten, M., Ellsworth, W.L., 2018. How faults wake up: the Guthrie-Langston, Oklahoma earthquakes. Lead. Edge 100-106. https://doi.org/ $10.1190 /$ tle37020100.1.

Scholz, C.H., 1998. Earthquakes and friction laws. Nature 391, 37-42.

Schorlemmer, D., Wiemer, S., 2005. Variations in earthquake-size distribution across different stress regimes. Nature 437, 539-542. https://doi.org/10.1038/ nature04094.

Segall, P., Fitzgerald, S.D., 1998. A note on induced stress changes in hydrocarbon and geothermal reservoirs. Tectonophysics 289, 117-128. https://doi.org/10.1016/ s00401951(97)00311-9.

Sheorey, P.R., 1994. A theory for in situ stresses in isotropic and transversely isotropic rocks. Int. J. Rock Mech. Min. Sci. Geomech. Abstr. 31, 23-34.

Sonder, L.J., 1990. Effects of density contrasts on the orientation of stresses in the lithosphere: relation to principal stress directions in the transverse ranges, California Tectonics 9, 761-771.

Sperner, B., Müller, B., Heidbach, O., Delvaux, D., Reinecker, J., Fuchs, K., 2003. Tectonic stress in the earth's crust: advances in the World Stress Map project. In: Nieuwland, D.A. (Ed.), New Insights in Structural Interpretation and Modelling. Geological Society, London, pp. 101-116. https://doi.org/10.1144/gsl.sp.2003.212.01.07.

Stein, R.S., 1999. The role of stress transfer in earthquake occurrence. Nature 402, 605609.

Steinberger, B., Schmeling, H., Marquart, G., 2001. Large-scale lithospheric stress field and topography induced by global mantle circulation. Earth Planet. Sci. Lett. 186, 75-91.

Tingay, M., Müller, B., Reinecker, J., Heidbach, O., Wenzel, F., Fleckenstein, P., 2005. Understanding tectonic stress in the oil patch: the World Stress Map Project. Lead. Edge 1276-1282.

Tingay, M.R.P., Müller, B., Reinecker, J., Heidbach, O., 2006. State and origin of the presentday stress field in sedimentary basins: new results from the World Stress Map Project. In: 41st U.S. Symposium on Rock Mechanics (USRMS): 50 Years of Rock Mechanics Landmarks and Future Challenges, Golden, Colorado, pp. 14

Tingay, M., Bentham, P., De Feyter, A., Kellner, A., 2011. Present-day stress field rotations associated with evaporites in the offshore Nile Delta. GSA Bull. 123, 1171-1180.

Townend, J., Zoback, M.D., 2006. Stress, strain, and mountain-building in central Japan. J. Geophys. Res. 111. https://doi.org/10.1029/2005JB003759.

Townend, J., Sherburn, S., Arnold, R., Boese, C., Woods, L., 2012. Three-dimensional variations in present-day tectonic stress along the Australia-Pacific plate boundary in New Zealand. Earth Planet. Sci. Lett. 353-354, 47-59. https://doi.org/10.1016/j. epsl.2012.08.003.

van Wees, J.-D., Osinga, S., van Thienen-Visser, K., Fokker, P.A., 2017. Reservoir creep and induced seismicity: inferences from geomechanical modeling of gas depletion in the Groningen field. Geophys. J. Int. 212, 1487-1497. https://doi.org/10.1093/gji/ ggx452. Voight, B., 1966. Beziehung zwischen großen horizontalen Spannungen im Gebirge und der Tektonik und der Abtragung, First Congress. Int. Soc. Rock Mech., Lisbon, pp. 5156.

Voight, B., Taylor, J.W., Voight, J.P., 1968. Tectonophysical implications of rock stress determinations. Geol. Rundsch. 58, 655-676.

Wallace, R.E., 1951. Geometry of shearing stress and relations to faulting. J. Geol. 59, 118130.

Walsh, F.R., Zoback, M., 2016. Probabilistic assessment of potential fault slip related to injection-induced earthquakes: application to north-central Oklahoma, USA. Geology 44, 991-994. https://doi.org/10.1130/G38275.1.

Warpinski, N.R., 1989. Determining the minimum in situ stress from hydraulic fracturing through perforations. Int. J. Rock Mech. Min. Sci. Geomech. Abstr. 26, 523-531.

Williams, J.D.O., Fellgett, M.W., Kingdon, A., Williamson, J.P., 2015. In-situ stress orientation in the UK Southern North Sea: regional trends, deviations and detachment of the post-Zechstein stress field. Mar. Pet. Geol. 67, 769-784.

https://doi.org/10.1016/j.marpetgeo.2015.06.008.

Xie, F.R., Chen, Q.C., Cui, X.F., et al., 2007. Fundamental database of crustal stress environment in continental China. Prog. Geophys. 22,131-136.

Zakharova, N.V., Goldberg, D.S., 2014. In situ stress analysis in the northern Newark Basin: implications for induced seismicity from $\mathrm{CO}_{2}$ injection. J. Geophys. Res. 2362-2374 https://doi.org/10.1002/2013JB010492.

Zang, A., Stephansson, O., 2010. Stress in the Earth's Crust, 1st ed. Springer, Heidelberg.

Zang, A., Stephansson, O., Heidbach, O., Janouschkowetz, S., 2012. World stress map database as a resource of rock mechanics and rock engineering. Geotech. Geol. Eng. 30, 625-646. https://doi.org/10.1007/s10706-012-9505-6.

Zang, A., Yoon, J.S., Stephansson, O., Heidbach, O., 2013. Fatigue hydraulic fracturing by cyclic reservoir treatment enhances permeability and reduces induced seismicity. Geophys. J. Int. https://doi.org/10.1093/gji/ggt1301.

Ziegler, M., Heidbach, O., 2017a. Matlab Script Stress2Grid. GFZ Data Services. https:// doi.org/10.5880/wsm.2017.002.

Ziegler, M., Heidbach, O., 2017b. Manual of the Matlab script Stress2Grid. In: World Stress Map Technical Report. GFZ German Research Centre for Geosciences, Potsdam, pp. 33. https://doi.org/10.2312/wsm.2017.002.

Ziegler, M., Heidbach, O., Reinecker, J., Przybycin, A.M., Scheck-Wenderoth, M., 2016a. A multi-stage 3-D stress field modelling approach exemplified in the Bavarian Molasse Basin. Solid Earth 7, 1365-1382. https://doi.org/10.5194/se-7-1365-2016.

Ziegler, M., Rajabi, M., Heidbach, O., Hersir, G.P., Ágústsson, K., Árnadóttir, S., Zang, A. 2016b. The stress pattern of Iceland. Tectonophysics 674, 101-113. https://doi.org/ 10.1016/j.tecto.2016.02.008.

Ziegler, M., Heidbach, O., Zang, A., Martínez-Garzón, P., Bohnhoff, M., 2017. Estimation of the differential stress from the stress rotation angle in low permeable rock. Geophys. Res. Lett. 44, 6761-6770. https://doi.org/10.1002/2017GL073598.

Zoback, M.L., 1992. First and second order patterns of stress in the lithosphere: the World Stress Map Project. J. Geophys. Res. 97, 11703-11728.

Zoback, M., 2010. Reservoir Geomechanics, $2^{\text {nd }}$ edition. Cambridge, Cambridge.

Zoback, M.L., Richardson, R.M., 1996. Stress perturbation associated with the Amazonas and other ancient continental rifts. J. Geophys. Res. B101, 5459-5475.

Zoback, M.L., Zoback, M., 1980. State of stress in the conterminous United States. J. Geophys. Res. 85, 6113-6156.

Zoback, M.L., Zoback, M., 1989. Tectonic stress field of the conterminous United States. In: Pakiser, L.C., Mooney, W.D. (Eds.), Geophysical Framework of the Continental United States. Geol. Soc. Am. Mem, Boulder, Colorado, pp. 523-539.

Zoback, M., Zoback, M.L., 1991. Tectonic stress field of North America and relative plate motions. In: Slemmons, D.B., Engdahl, E.R., Zoback, M.D., Blackwell, D.D. (Eds.), Neotectonics of North America. Geological Society of America, Boulder, Colorado, pp. 339366.

Zoback, M., Moos, D., Mastin, L., 1985. Well bore breakouts and in situ stress. J. Geophys. Res. 90, 5523-5530.

Zoback, M.L., Zoback, M., Adams, J., Assumpção, M., Bell, S., Bergman, E.A., Blümling, P. Brereton, N.R., Denham, D., Ding, J., Fuchs, K., Gay, N., Gregersen, S., Gupta, H.K. Gvishiani, A., Jacob, K., Klein, R., Knoll, P., Magee, M., Mercier, J.L., Müller, B.C., Paquin, C., Rajendran, K., Stephansson, O., Suarez, G., Suter, M., Udías, A., Xu, Z.H., Zhizhin, M., 1989. Global patterns of tectonic stress. Nature 341, 291-298.

https://doi.org/10.1038/341291a0.h 